\title{
Review \\ Diversity and Distribution of Theileria Species and Their Vectors in Ruminants from India, Pakistan and Bangladesh
}

\author{
Jehan Zeb ${ }^{1,2}$, Baolin Song ${ }^{1}$, Muhammad Umair Aziz ${ }^{1}$, Sabir Hussain ${ }^{1}{ }^{(}$, , Riaz Zarin ${ }^{3}$ and Olivier Sparagano ${ }^{1, *(1)}$ \\ 1 Department of Infectious Diseases and Public Health, Jockey Club College of Veterinary Medicine and Life \\ Sciences, City University of Hong Kong, Kowloon, Hong Kong SAR, China; jehanzeb2@cityu.edu.hk (J.Z.); \\ Baolin.Song@my.cityu.edu.hk (B.S.); muhamaziz3-c@my.cityu.edu.hk (M.U.A.); \\ sahussain8-c@my.cityu.edu.hk (S.H.) \\ 2 Department of Zoology, Abdul Wali Khan University Mardan, Mardan 23200, Pakistan \\ 3 Elementary \& Secondary Education Department Government of Khyber Pakhtunkhwa, \\ Chitral 17200, Pakistan; geospatial571@gmail.com \\ * Correspondence: olivier.sparagano@cityu.edu.hk
}

check for updates

Citation: Zeb, J.; Song, B.; Aziz, M.U.; Hussain, S.; Zarin, R.; Sparagano, O. Diversity and Distribution of Theileria Species and Their Vectors in Ruminants from India, Pakistan and Bangladesh. Diversity 2022, 14, 82. https://doi.org/10.3390/d14020082

Academic Editor: Michael Wink

Received: 28 December 2021

Accepted: 19 January 2022

Published: 25 January 2022

Publisher's Note: MDPI stays neutral with regard to jurisdictional claims in published maps and institutional affiliations.

Copyright: (c) 2022 by the authors Licensee MDPI, Basel, Switzerland. This article is an open access article distributed under the terms and conditions of the Creative Commons Attribution (CC BY) license (https:// creativecommons.org/licenses/by/ $4.0 /)$.

\begin{abstract}
Tropical theileriosis, caused by the apicomplexan hemoparasite of the genus Theileria, is a major constraint to livestock production in various parts of world, including South Asia. Several studies have been carried out over the last five decades; however, comprehensive information in this region regarding the diversity and distribution of Theileria is lacking. Therefore, keeping in mind the economic importance of theileriosis, we have systematically reviewed the current knowledge about Theileria spp. diversity and distribution affecting cattle, water buffaloes, goats and sheep in three countries included India, Pakistan and Bangladesh of the Indian sub-continent. The data collected indicated that the microscopic method is the widely used method for evaluating Theileria species in the three countries from 1970 to 2021. This is the first study in this region to compile a comprehensive knowledge about the diversity and distribution of Theileria. Our study revealed the existence of 11 different species of Theileria, including Theileria spp. Theleria annulata, T. orientalis, T. mutans, T. velifera circulating in cattle and buffalo while T. annulata, T. lestoquardi, T. luwenshuni T. ovis, Theileria spp. and T. lestoquardi-like spp., were infecting goats and sheep from various regions of India, Pakistan and Bangladesh. We find that T. annulata can be found in both small and large ruminants and is widely distributed in the different regions of India, Pakistan and Bangladesh. In addition, our analysis revealed that the existence of possible tick vectors of the genera Hyalomma, Haemophysalis, Rhipicephalus and Amblyomma may be responsible for the diverse and wide distribution of different Theileria species. However, the competence of these tick vectors for different Theileria species still need to be explored. Therefore, further studies are needed to bridge this gap and to improve the health and production of livestock and reduce economic losses due to theileriosis in India, Pakistan and Bangladesh. Furthermore, we selected representative $18 \mathrm{~S}$ rRNA sequences for T. annulata from the different regions to infer phylogenetic relationship. Phylogenetic analysis of the selected isolates clustered in different clades which might be due to the variation in a hypervariable region of $18 \mathrm{~S}$ $r R N A$. The outcome of this analysis is expected to provide a coherent and integrated framework about the different Theileria species prevailing in these countries and contribute to improving the surveillance and control plans of various Theileria species in the region.
\end{abstract}

Keywords: diversity; distribution; Theileria; tick vectors; South Asia

\section{Introduction}

Tick-borne diseases (TBDs) are considered to be one of the main threats to the ruminants' health in both tropical and sub-tropical regions of the world, representing a serious obstacle to livestock farming. Several TBDs cause significant economic losses associated 
with high mortality rate and decreased production output in domestic livestock worldwide [1,2]. Among these, theileriosis is considered one of the significant tick-borne diseases and a major constraint in the growth of the livestock business in many areas of the world [3,4] (Ica et al., 2007; Jenkins 2018). It causes severe morbidity and mortality in livestock, reducing meat and milk production, leading to significant economic losses each year worldwide. The estimated range of economic losses due to theileriosis is 5-25\% of the total farm losses worldwide [5]. Resource-poor farming communities are at a greater risk due to the lack of systematic acaricide use and limited access to veterinary health care centers leading to a high mortality rate in untreated animals [6,7].

The lifecycle of Theileria parasites in the ruminant host and tick vector has been reviewed [8,9]. Shortly, the lifecycle of Theileria is completed in two stages i.e., the vertebrate host stage (asexual reproduction) and tick vector stage (sexual reproduction). The lifecycle begins when an infected tick bites and transmits sporozoites into vertebrate hosts during blood-feeding, where it may transform into schizonts [10]. Subsequently, upon releasing from the infected leukocytes, the merozoites may infect host erythrocytes (RBCs) and then develop into piroplasms. Further multiplication of the piroplasms (merogony) takes place in the RBCs [11]. In non-transforming Theileria, merogony has been observed in RBCs [12]. Finally, the tick acquires blood-stage Theileria parasites including the gametes, when they feed on an infected host. Sexual reproduction of the gametes occurs in the midgut of the competent vector tick species, where, during meiosis, genetic recombination occurs $[13,14]$. In this way, Theileria parasites' transmission occurs trans-stadially by the tick vectors, and therefore, the known transmission vectors may be 2- or 3-host tick species [9]. The modified form of life cycle of Theileria species is shown in Figure 1.

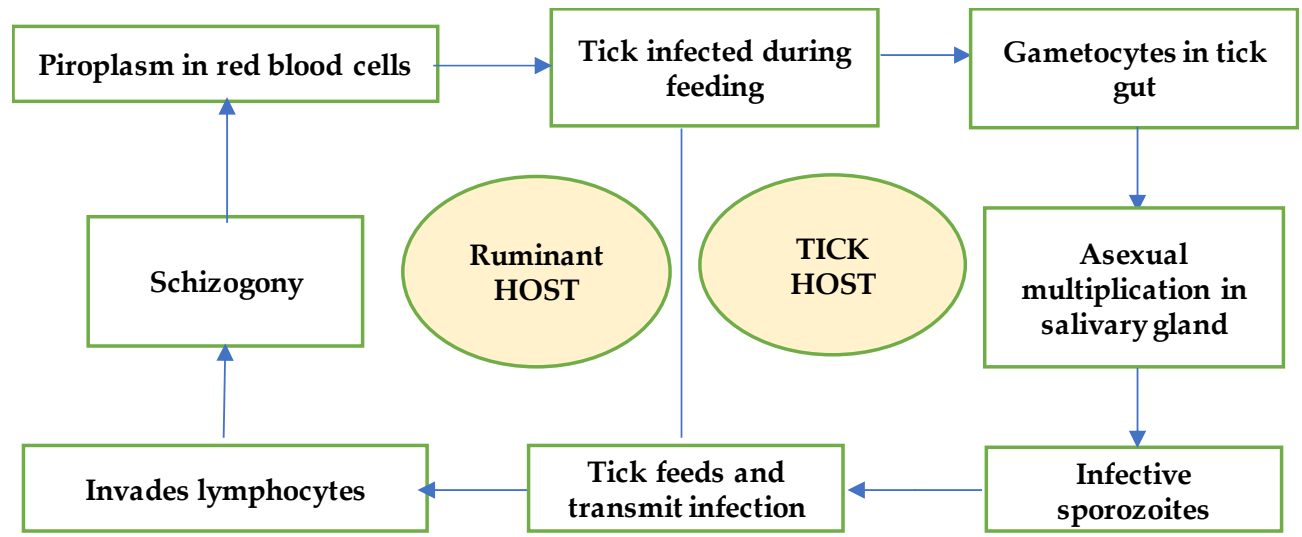

Figure 1. Life cycle of Theileria showing different stages in ruminants and tick hosts.

Theileria is distributed worldwide and is a significant cause of disease in livestock in tropical and subtropical regions of the world, including Asia. The most pathogenic and economically important Theileria species infecting large ruminants (Cattle; Bos Taurus and Bos indicus, and water buffalo; Bubalus bubalis) are T. annulata, which causes Tropical theileriosis (TT) or Mediterranean theileriosis, T. parva, which causes East Coast fever (ECF), and T. mutans, which causes benign theileriosis and T. orientalis, (T. orientalis/buffeli group), which causes Oriental theileriosis (OT) or Theileria-associated bovine anemia (TABA). However, on the other hand, T. lestoquardi, which causes malignant ovine theileriosis (MOT) T. uilenbergi and T. luwenshuni are the most pathogenic species of economic significance infecting small ruminants (goats; Capra aegagrus hircus and sheep; Ovis aries), T. taurotragi, and T. ovis, mostly cause asymptomatic infections in livestock [2,15]. Depending upon the Theileria species, different tick vector species of the genera Hyalomma, Rhipicephalus, Haemaphysalis, and Amblyomma are involved in disease transmission [16].

Different diagnostic techniques are used for the detection of Theileria. Most widely used and standard techniques are Giemsa-stained blood smears and lymph node needle biopsy smears. These methods are more useful in acutely infected animals than the chroni- 
cally infected carriers due to the low level of parasitaemia. Furthermore, species-specific identification based on Giemsa staining is difficult as most Theileria piroplasms share morphological identity except for T. parva, T. annulata and T. velifera. Similarly, schizonts cannot always be detected in the superficial lymph nodes during the disease time. In addition, these methods need more field investigation [15,17]. As an alternative, a serological method for detecting parasites antibodies has been developed. However, these methods may only detect previous exposure to the infection as compared to the current one due to its poor sensitivity and specificity $[15,18]$. New advanced techniques such as next-generation genomic resources have been adapted to overcome these limitations of traditional gross parasitological diagnostic techniques. Different piroplasm species can be differentiated based on variations in the hyper-variable region of $18 \mathrm{~S}$ rDNA sequence [19-25]. For the amplification of the $18 \mathrm{~S}$ region, various PCR methods like reverse line blot (RLB)-PCR, quantitative PCR (qPCR) and multiplex PCR have been described to [19,26-28].

The seasonal fluctuations have been found as one of the important risk factors that affect the distribution of this parasite. There are several species of this parasite, and they have substantial differences in their ecoepidemiology in significant parts of the Asian countries including India, Pakistan and Bangladesh. In addition, lack of proper management practices in these areas may lead to heavy economic losses [29-31]. Keeping in view the importance of the above discussion, the present review data related to the Theileria species diversity infecting ruminant species and distribution concerning its tick vectors in specific region of the Asia including India, Pakistan and Bangladesh. The outcome of this analysis is expected to provide an integrated scientific baseline for future vaccination programs and other control measures either at the pathogen or vector level.

\section{Materials and Methods}

\subsection{Study Protocol}

In this review study, we systemically reviewed the relevant articles published on Theileria in small and large ruminants in the three important countries from the livestock perspectives of South Asia, including India, Pakistan and Bangladesh as shown in Figure 2. The different studies were divided into various zones based on administrative and geomorphic features such as India divided into five zones viz Central, North, East, North-east, West, South, while Pakistan divided into four provinces such as Punjab, Khyber Pakhtunkhwa, Sindh and Balochistan and FATA and Bangladesh was divided into six zones like Central, South Eastern, North Central, Northern, and Western.

\subsection{Literature Search Strategy}

Our procedure was based on searching different databases such as PubMed, Science Direct, Springer, Scopus, Google Scholar and Web of Science for retrieving relevant articles published in these three countries, which mainly focused on the time period from 1970 to 2021. Furthermore, to back trace the past years published articles on Theileria, all collected peer- reviewed articles, and references cited from the retrieved studies were searched again. Different terms such as Theileria, tick borne pathogens, Theileria vectors, tick vectors, large ruminants, small ruminants, and region of the concerned country were used for retrieving data.

\subsection{Data Extraction and Qualitative Assessment}

The diversity and distribution studies were analyzed carefully and reviewed systematically before initiating the data entry process onto predesigned Microsoft Excel 2010 sheets. To further maximize the accuracy, the extracted information compiled in Microsoft Excel 2010 by the author (JZ) was screened to remove repeated studies. After the data were entered, another author (OS) checked the dataset thoroughly to avoid errors, duplications and to further enhance the quality of extracted data. 
Theileria Species Name Country: Pakistan Host: Cattle and Baffaloes

T. annulata

$\mathrm{T}$. orientalis

Theileria spp

Host: Goats and sheep

T. annulata

T. lestoquardi

T. luwenshuni $T$. ovis

Theileria spp.

lestoquardi-like spp.

Country: India

Host: Cattle and Baffaloes

T. orientalis, T. mutans

T. velifera

Theileria spp. T. annulata

Host: Goats and sheep

T. luwenshuni \& $T$ ovis

Theileria spp. T. lestoquardi

Country: Bangladesh

Country: Bangladesh

Host: Cattle and Baffaloes

T. Mutans

T. orientalis

Theileria Spp. T. annulata

Host: Goats and sheep

T. annulata

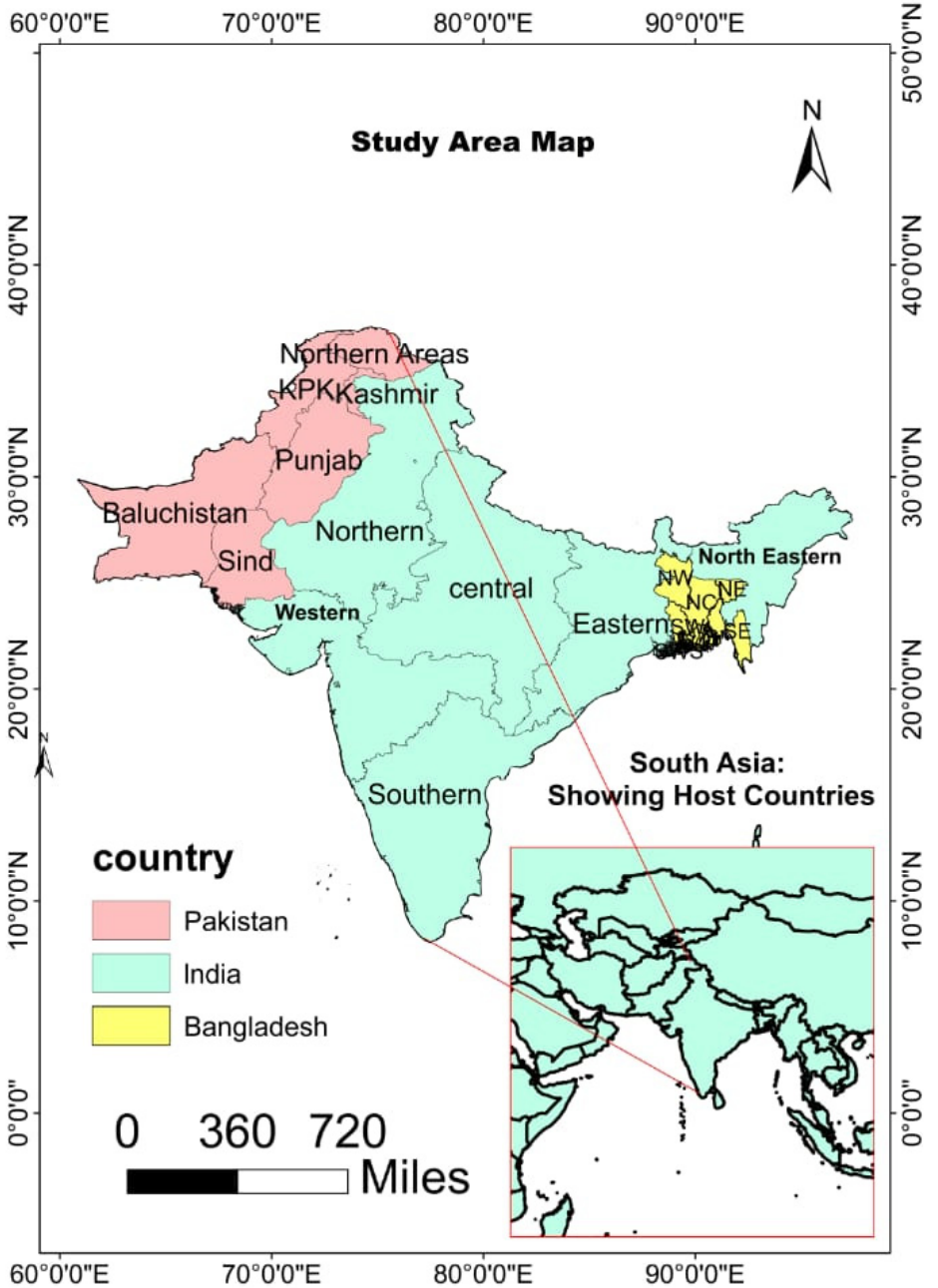

Figure 2. Map showing the location of the study area (India, Pakistan, and Bangladesh) and a list of Theileria Species present in each country.

Furthermore, all studies regarding Theileria/theileriosis conducted on large (cattle and buffaloes) and small ruminants (goats and sheep) in the region were selected for analysis. Five key pieces of information was extracted from the literature: (1) Theileria species and possible tick vectors detection (2) region, state or location of the study, (3) time of the study conducted, (4) study type and (5) studies that have used the standard methodology of confirmatory tests including blood smear examination with different staining methods, molecular methods by different PCRs, and serological diagnosis.

During the first step of screening, 410 articles, including $n=250$ from India, $n=130$ from Pakistan and $n=30$ from Bangladesh were retrieved. Following the data retrieval step, the data were compiled in Microsoft Excel 2010 and all the duplicated studies $n=60$ were removed from further screening while $n=130$ theses and full length papers which were not available online were also excluded. In addition, all the irrelevant data and papers $(n=75)$ published in a language other than English were also removed. To further enhance the quality assessment, we removed the conference proceedings, which were not available with full text. Finally, a total of 136 were identified to be eligible for data analysis which included $n=67, n=56$ and $n=13$ from India, Pakistan and Bangladesh, respectively (Figure 3). The studies were carried out between 1975 and 2021, and were grouped in three different periods: (1) 1975-2010, (2) 2011-2015, (3) 2016-2021, and were differentiated between molecular and direct diagnostic tests, as shown in Figures 4 and 5. 


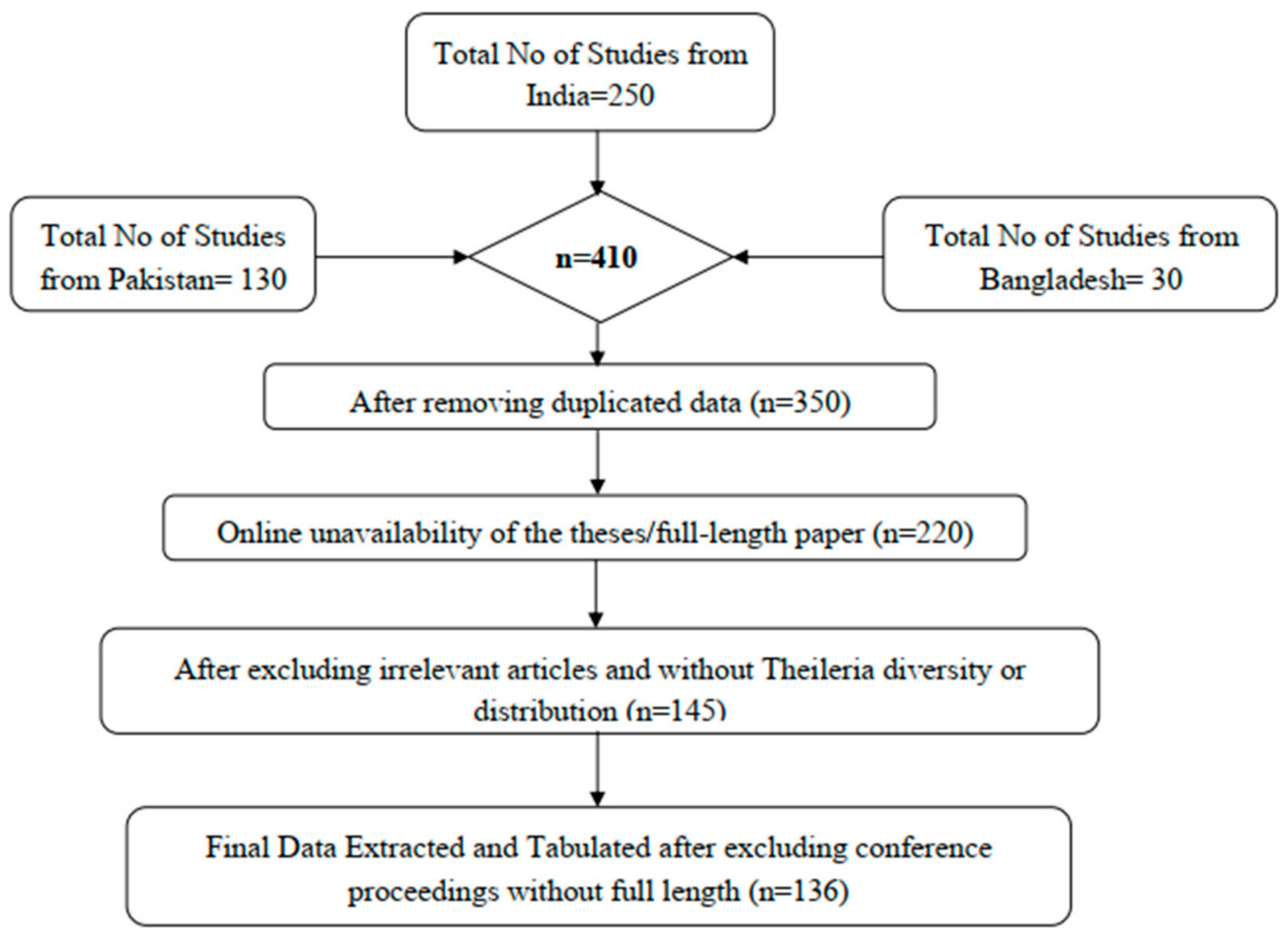

Figure 3. Flow chart diagram showing the data retrieving and extraction procedure.

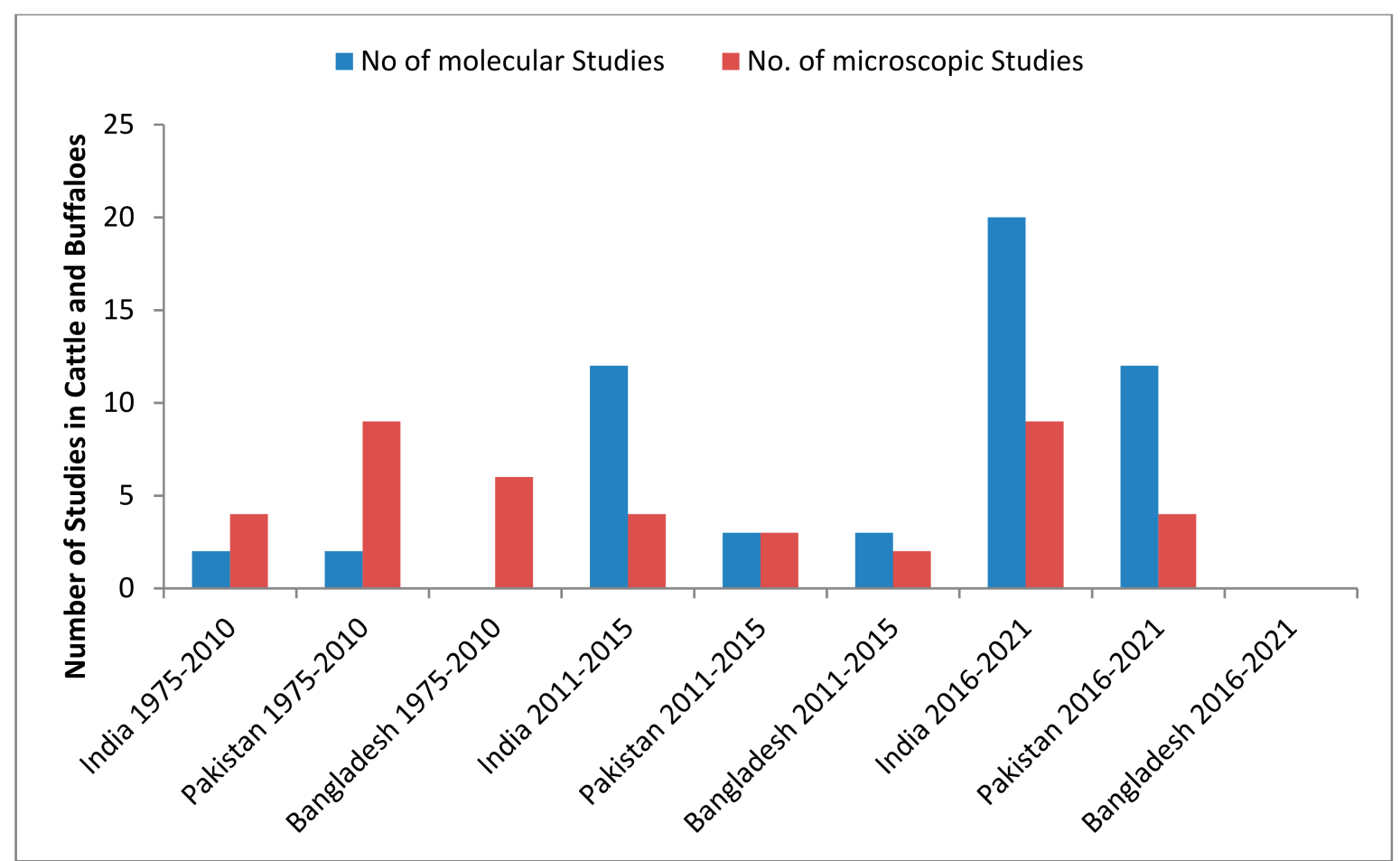

Figure 4. Comparison of the number of epidemiological studies detecting Theileria spp. in water buffalo and cattle using molecular and microscopic diagnostic methods in India, Pakistan and Bangladesh, according to three different periods between 1975 and 2021. 


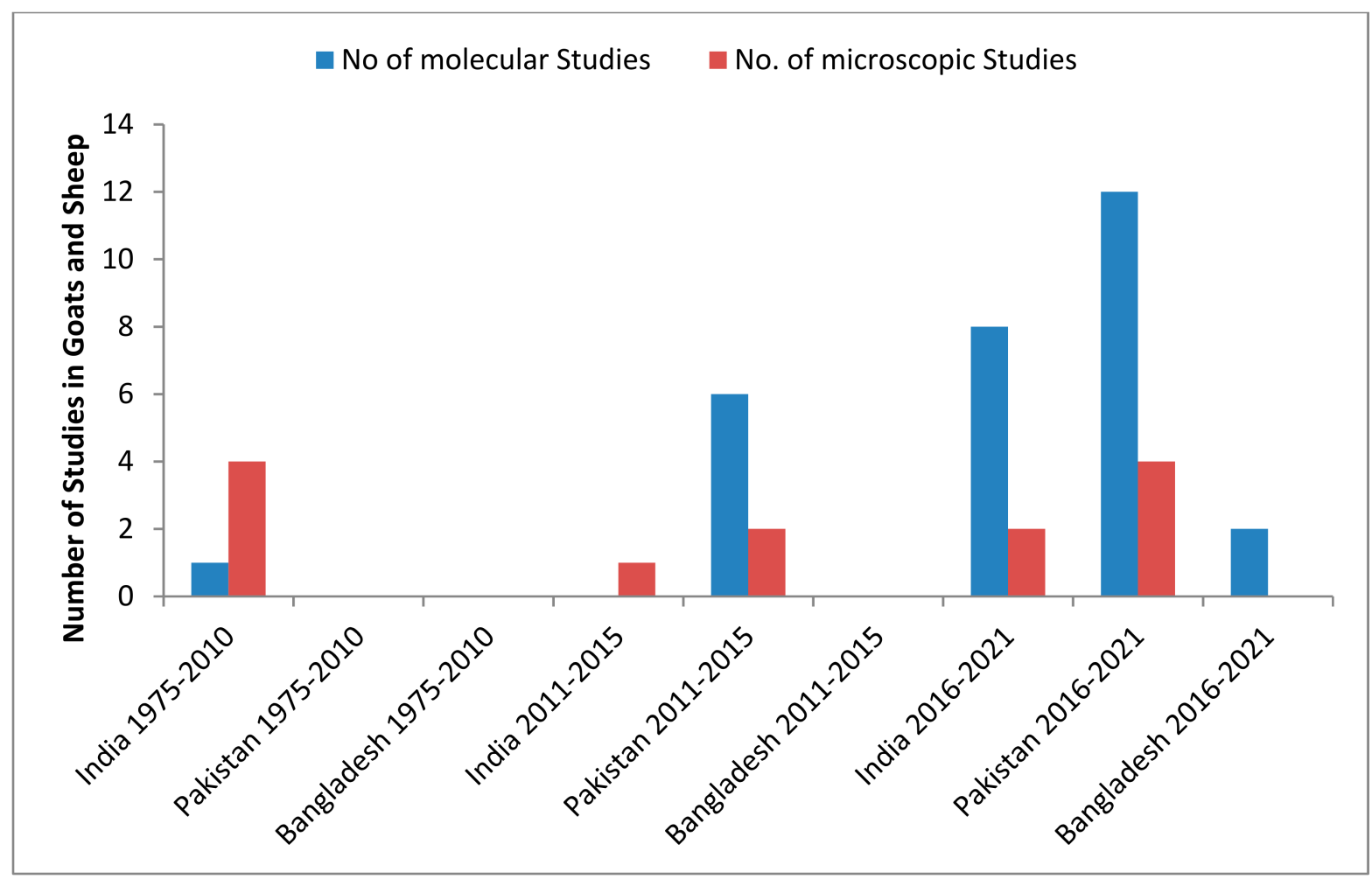

Figure 5. Comparison of the number of epidemiological studies detecting Theileria spp. in goats and sheep using molecular and microscopic diagnostic methods in India, Pakistan and Bangladesh, according to three different periods between 1975 and 2021.

\subsection{Phylogenetic Analysis and Evolutionary Divergence}

Representative sequences with accession numbers were selected from the previously published studies and were used for phylogenetic and evolutionary (genetic) divergence analysis. The sequences selected from the different regions of India were included, MF287947.1 (Central India), MF287920.1, (West India), MF287949.1 (Eastern India), MF287937.1 T_annulata South India and MF287934.1 (North India) while sequences with accession numbers from Pakistan are included JQ743631.1 (Pakistan), JQ743636.1, (Pakistan), MW046053.1 (Pakistan) and MW046054.1 (Pakistan). The phylogenetic tree of the selected $T$. annulata isolates was inferred using the $18 S \mathrm{r} R N A$ genetic marker. Phylogenetic analyses were conducted with a Tamura 3-parameter $(\mathrm{T} 92+\mathrm{G})$ Model using MEGA version 7.0 [32]. CLUSTAL $\mathrm{W}$ alignment was performed to align the selected sequences retrieved from the GenBank. The neighbor-joining algorithm was used to establish the phylogenetic analysis. Bootstrap values were obtained with 1000 replicates.

\section{Results and Discussion}

\subsection{Diversity and Distribution of Theileria Species Infecting Livestock}

A general overview of the Theileria species identified in the three countries is depicted in the Table 1. We have collected the data regarding different species of Theileria infecting livestock i.e., large (cattle \& buffalo) and small ruminants (goats \& sheep) conducted in the different geographical regions of the three selected countries of South Asia. Our analysis revealed that different species of Theileria in these countries circulating in large ruminants include T. annulata, T. orientalis T. mutans, T. Ovis and T. velifera and Theileria spp., while in small ruminants, the different species of Theileria reported were T. annulata, T. lestoquardi, T. luwenshuni T. ovis, Theileria spp. and T. lestoquardi-like spp. from various geographical locations of India, Pakistan and Bangladesh. Among these, the most common and widespread species circulating in all ruminants is T. annulata. 
Table 1. Common Theileria species found in India, Pakistan and Bangladesh.

\begin{tabular}{|c|c|c|}
\hline Country & Host & Theileria Species Name \\
\hline India & $\begin{array}{l}\text { Cattle \& Buffaloes } \\
\text { Goats \& Sheep }\end{array}$ & $\begin{array}{l}\text { Theileria spp. T. annulata, T. orientalis, T. mutans \& T. velifera } \\
\text { Theileria spp. T. lestoquardi T. luwenshuni \& T. ovis }\end{array}$ \\
\hline Pakistan & $\begin{array}{l}\text { Cattle \& Buffaloes } \\
\text { Goats \& Sheep }\end{array}$ & $\begin{array}{c}\text { T. annulata, T. orientalis \& Theileria spp. } \\
\text { T. annulata, T. lestoquardi, T. luwenshuni T. ovis \& Theileria spp. T. lestoquardi-like spp. }\end{array}$ \\
\hline Bangladesh & $\begin{array}{l}\text { Cattle \& Buffaloes } \\
\text { Goats \& Sheep }\end{array}$ & $\begin{array}{c}\text { Theileria spp. T. annulata, T. orientalis, T. Mutans, } \\
\text { T. annulata }\end{array}$ \\
\hline
\end{tabular}

\subsection{Diversity and Distribution of Theileria Species Infecting Livestock in the Different Regions of India}

Theileria species reported from different regions of India are listed in Table 2. According to the data collected, only one species of Theileria reported in cattle and buffalo from the central region of India is T. annulata, [33,34] while, on the other hand, in Eastern India, two species of Theileria. (T. mutans \& T. velifera) were identified; however, no Theileria species were reported in small ruminants from these two regions $[35,36]$. Furthermore, Theileria species identified in the large ruminants from South India included Theileria spp., T. annulata [37-39] and new T. orientalis genotype [40-43], whereas, in East and North East India, trans placental transmission of T. annulata in young borne calves and its detection in tick Hy. anatolicum has been identified [44,45]. In the case of small ruminants, T. lestoquardi was identified molecularly. T. luwenshuni \& T. ovis [46-48] were detected in South India while only T. luwenshuni has been recorded in the East and Northeast region of India [49,50]. Furthermore, Theileria spp., [51] T. annulata, [52-57] and T. orientalis [58] were detected to be circulating in cattle and buffalo while T. annulata, [59], Theileria spp. [60] and T. luwenshuni [61-63] were found infecting goats and sheep (small ruminants) from West Bangal and North India. The difference in the distribution of diversity of various Theileria species in different regions may be attributed to various factors such as competent vector tick species, geo-climatic conditions favoring different vector tick species growth, lack of education of farmers, and improper use of acaricidal use.

Table 2. Regional wise distribution of Theileria Species in different regions of India.

\begin{tabular}{|c|c|c|c|c|c|}
\hline \multicolumn{6}{|c|}{ India } \\
\hline Province/State & Theileria spp. & Identification Method & Host & Year of Study & References \\
\hline \multicolumn{6}{|c|}{ Central India } \\
\hline \multicolumn{6}{|c|}{ Cattle \& Buffaloes } \\
\hline Central India & T. annulata & Microscopy & Ticks \& Cattle & 1975 & {$[64]$} \\
\hline Uttar Pradesh & T. annulata & Molecular & Cattle & 1977 & {$[65]$} \\
\hline Uttar Pradesh & T. annulata & Microscopy & Cattle & 2012 & [66] \\
\hline Uttar Pradesh & T. annulata & Molecular & Cattle & 2015 & [67] \\
\hline Chhattisgarh & T. annulata & Microscopy & Cattle & 2016 & [34] \\
\hline Central India & T. annulata & Molecular & Cattle & 2017 & [68] \\
\hline Uttar Pradesh & T. annulata & Molecular & Cattle & 2018 & [69] \\
\hline Hisar & T. annulata & Microscopy & Cattle & 1989 & [33] \\
\hline \multicolumn{6}{|c|}{ Eastern India } \\
\hline West Bangal & T. annulata & Molecular & Cattle & 2003 & [35] \\
\hline Guinea & T. mutans \& T. velifera & Molecular & Cattle & 2021 & [36] \\
\hline \multicolumn{6}{|c|}{$\begin{array}{l}\text { Molecular } \\
\text { South India }\end{array}$} \\
\hline North Banglore & T. annulata & Microscopy & Cattle & 2009 & [37] \\
\hline Kerala & Theileria spp. \& T. annulata & Microscopy \& Molecular & Cattle & 2011 & [38] \\
\hline South India & T. orientalis & Molecular & Cattle & 2011 & {$[70]$} \\
\hline South India & T. annulata \& Theileria spp. & Molecular & Cattle & 2013 & {$[40]$} \\
\hline Tamil Nadu & Theileria spp. & Microscopy & Cattle & 2014 & [71] \\
\hline \multirow{2}{*}{$\begin{array}{c}\text { Telangana and } \\
\text { Andhra Pradesh } \\
\text { Karnataka }\end{array}$} & T. orientalis & Molecular & Cattle & 2015 & {$[41]$} \\
\hline & T. annulata & Microscopy & Cattle & 2016 & [42] \\
\hline
\end{tabular}


Table 2. Cont.

\begin{tabular}{|c|c|c|c|c|c|}
\hline \multicolumn{6}{|c|}{ India } \\
\hline Province/State & Theileria spp. & Identification Method & Host & Year of Study & References \\
\hline Southwest India & T. annulata & Microscopy & Buffalo \& Cattle & 2016 & [39] \\
\hline Karnataka & T. annulata & Microscopy & Cattle & 2017 & [72] \\
\hline Kerala & T. orientalis & Molecular & R. annulatus Ticks & 2019 & [43] \\
\hline South India & Theileria spp. & $\begin{array}{c}\text { Molecular } \\
\text { Goats \& Sheep }\end{array}$ & Ticks \& Cattle & 2021 & {$[73]$} \\
\hline West Bengal & T. hirci (T. lestoquardi) & Microscopy & Goat & 1990 & [46] \\
\hline Karnataka & Theileria spp. & Microscopy & Sheep & 1985 & [74] \\
\hline South India & Theileria spp. & Microscopy & Goat \& Ticks & 2017 & [47] \\
\hline Kerala & Theileria spp. & Microscopy \& Molecular & Goats & 2017 & [75] \\
\hline Karnataka & T. luwenshuni & Molecular & Goats \& Sheep & 2017 & [48] \\
\hline Karnataka & T. luwenshuni \& T. ovis & Molecular & Sheep & 2019 & [76] \\
\hline Karnataka & Theileria spp. & Microscopy & Sheep & 2020 & [77] \\
\hline Assam & T. annulata \& T. orientalis & Molecular & Cattle & 2015 & [78] \\
\hline Odisha & T. annulata \& T. orientalis & Microscopy \& Molecular & Cattle & 2017 & [79] \\
\hline Odisha & T. annulata & Microscopy and Molecular & Cattle & 2017 & [80] \\
\hline Odisha & T. orientalis & Molecular & Cattle & 2020 & [81] \\
\hline Odisha & T. annulata & Molecular & Cattle & 2021 & [44] \\
\hline Odisha & T. annulata & Molecular & Cattle & 2021 & [45] \\
\hline & & Goats \& Sheep & & & \\
\hline Assam & T. luwenshuni & Microscopy \& Molecular & Goat & 2018 & {$[50]$} \\
\hline Guwahati of Assam & T. luwenshuni & $\begin{array}{c}\text { Microscopy \& Molecular } \\
\text { West India }\end{array}$ & Goat & 2019 & [49] \\
\hline Anand & T. annulata & Molecular & Buffalo \& Cattle & 2014 & [52] \\
\hline Gujrat & T. annulata & Microscopy and Molecular & Cattle & 2015 & [54] \\
\hline Gujrat & T. annulata & Microscopy \& Molecular & Cattle \& Buffalo & 2015 & [53] \\
\hline Maharashtra & T. annulata \& T. orientalis & Molecular & Cattle & 2017 & [58] \\
\hline Bihar & T. annulata & Microscopy & Buffalo & 2018 & [82] \\
\hline Anand & T. annulata \& T. orientalis & Molecular & Cattle & 2019 & [55] \\
\hline $\begin{array}{c}\text { Maharashtra \& } \\
\text { tamil Nadu }\end{array}$ & T. annulata & Molecular & Buffalo \& Cattle & 2019 & [58] \\
\hline $\begin{array}{l}\text { Telangana, Gujarat, } \\
\text { Haryana, and Bihar }\end{array}$ & T. annulata & Molecular & Vaccine Isolate & 2019 & {$[83]$} \\
\hline Maharashtra & Theileria spp. & Microscopy & Buffalo & 2020 & [51] \\
\hline Bihar & Theileria spp. & Microscopy & Cattle & 2021 & [84] \\
\hline Tamil Nadu & T. annulata & Molecular & Cattle & 2021 & [57] \\
\hline Bihar & T. annulata & Microscopy \& Molecular & Cattle & 2021 & [85] \\
\hline Haryana & T. annulata & Microscopy & $\begin{array}{c}\text { Goat, cattle, sheep } \\
\text { Sera }\end{array}$ & 1998 & [86] \\
\hline Tamil Nadu & Theileria Spp. & Microscopy & Sheep & 2005 & [87] \\
\hline Haryana & T. annulata & Molecular & Tick & 2006 & [59] \\
\hline Tamil Nadu & Theileria spp. & Microscopy & Goats \& Sheep & 2015 & [60] \\
\hline Tamil Nadu & T. luwenshuni & Molecular & Gaots \& Sheep & 2019 & [61] \\
\hline Maharashtra & T. luwenshuni & Microscopy \& Molecular & Sheep & 2021 & [62] \\
\hline Punjab & T. annulata & Microscopy & $\begin{array}{c}\text { Tick Hy. } \\
\text { anatolicum }\end{array}$ & 2010 & [88] \\
\hline Gujrat & Theileria spp. & Microscopy & Buffalo \& Cattle & 2021 & [89] \\
\hline Ludhiana Punjab & T. annulata & Microscopy & Cattle & 2012 & [90] \\
\hline Punjab & T. annulata & Molecular & Cattle & 2015 & [91] \\
\hline Ludhiana Punjab & T. annulata & Molecular & Tick \& Cattle & 2015 & [92] \\
\hline Rajasthan & Theileria & Microscopy & Cattle & 2015 & [93] \\
\hline Uttara hand & Theileria genus & Microscopy \& Molecular & Cattle & 2014 & [94] \\
\hline Haryana & T. annulata & Microscopy & Cattle & 2017 & [95] \\
\hline Haryana & T. annulata & Molecular & Cattle & 2020 & [96] \\
\hline $\begin{array}{l}\text { Telangana, Gujarat, } \\
\text { Haryana, and Bihar }\end{array}$ & T. annulata & Molecular & Vaccine & 2021 & {$[83]$} \\
\hline Gujrat & T. annulata & Molecular & Cattle & 2021 & [97] \\
\hline Himachal Pradesh & T. orientalis & Molecular & Cattle & 2021 & [98] \\
\hline & & Goats \& Sheep & & & \\
\hline Himachal Pradesh & T. luwenshuni & Molecular & Goats \& Sheep & 2021 & [63] \\
\hline
\end{tabular}

\subsection{Possible Tick Vectors for Theileria Species in India}

The diverse array of Theileria species in the region may be due to different tick vectors infesting livestock, which is shown in Table 3. Several studies have reported different vector tick species from different regions of India included R. microplus Hae. Bispinosa 
Hy. truncatum Hy. dromedarii Hy. anatolicum R. Sanguineous [70,78,99]. It may be assumed that the presence of different species of Theileria circulating in large and small ruminants may be linked to the presence of a wide variety of these tick vectors in the particular area as these ticks have the potential to transmit various Theileria species reported from other parts of the world $[100,101]$. For example, it has been found in Uttar Pradesh that H. anatolicum and $R$. appenticulatus could play a vector role in the T. annulata and T. lestoquardi transmission in large and small ruminants, respectively [64]. Similarly, Hy. anatolicum and R. microplus Hy. $m$. isaaci have been identified to transmit T. annulata in cattle, while, in buffalo, Hy. anatolicum may be the only vector transmitting T. buffeli (T. orientalis). On the other hand, Hy. anatolicum and Haemaphysalis are widely distributed in different regions of India [64,102], which may transmit various species of Theileria such as T. lestocardi (hirci) and other Theileria species in goats and sheep. Recently, in India, some studies have also confirmed the role of various tick species such as R. microplus, Hy. anatolicum and Hae. bispinosa in the transmission of T. orientalis [70,78]. Similar reports have been observed in Africa [103]. Besides the above-mentioned tick species, Hy. detritum, Hy. dromedarii, and Hy. lusitanicum can also be the potential vectors for the transmission of this pathogen in different hosts [9].

Table 3. Distribution of the possible vector tick species of Theileria in different regions of India.

\begin{tabular}{|c|c|c|c|}
\hline Tick Species & Host & States/Region & References \\
\hline $\begin{array}{l}\text { R. microplus. } R \text {. } \\
\text { haemaphysaloides }\end{array}$ & Cattle \& Buffalo & $\begin{array}{c}\text { It is found in all places except Manipur, Kerala, Nagaland, } \\
\text { Tripura \& Maharashtra }\end{array}$ & {$[78,102]$} \\
\hline Hy. anatolicum & Ruminants & $\begin{array}{l}\text { It may be present in all parts except Andhra Pradesh, } \\
\text { Jharkhand, Manipur, Mega laya, Stkin, Tripuri }\end{array}$ & {$[33,46,103]$} \\
\hline Hae. Bispinosa & Goats \& Sheep & $\begin{array}{l}\text { Widely distributed except Delhi, Haryana, Kerala, } \\
\text { Nagaland, Uttar Pradesh and Chhattisgarh }\end{array}$ & {$[47,64,70,99]$} \\
\hline Hy. truncatum & Goats \& Sheep & It is restricted to only Gujrat, Maharashtra \& Uttar Pradesh & [102] \\
\hline Hy. dromedarii & Goats \& Sheep & $\begin{array}{l}\text { It can be found only in Andhra Pradesh, Delhi, Gujrat, } \\
\text { Haryana, Himachal Pradesh, Jammu \& Kashmir, Odisha, } \\
\text { Punjab, Rajasthan, Uttar Pradesh }\end{array}$ & [102] \\
\hline R. Sanguineus & Goats \& Sheep & $\begin{array}{l}\text { It is reported from all places except Gora, Delhi, Manipur, } \\
\text { Megha laya, Nagaland, Tripuri and Uttar Pradesh }\end{array}$ & {$[47,64,102]$} \\
\hline
\end{tabular}

\subsection{Diversity and Distribution of Theileria Species in Different Regions of Pakistan}

Theileria species that have been reported in different provinces of Pakistan are listed in Table 4. Approximately three different species of Theileria, including Theileria spp., T. annulata and T. orientalis have been reported in cattle and buffalo from different places of the Punjab province. Among these, the predominant and widely distributed pathogen is T. annulata, which many authors have reported across the province either microscopically or molecularly [104-107]. In addition to T. annulata, other Theileria species such as T. orientalis [108-110] and Theileria spp. have also been identified recently [111-113]. On the other hand, different species of Theileria identified in small ruminants (goats and sheep) from various geographic areas of Punjab included Theileria spp. and T. annulata, [114-116] T. ovis and T. ovis, T. lestoquardi, [115,117-119]. In Khyber Pakhtunkhwa province, several studies from different areas investigated that $T$. annulata is the only species circulating in cattle and buffalo [101,120-122]; however, diverse species of Theileria such as T. annulata, T. lestoquardi, T. luwenshuni T. ovis and Theileria spp. have been identified in goats and sheep [123-126]. Theileria spp. and T. annulata were identified in cattle and buffalo from Sindh and Balochistan Province [116,127]. No single study has reported Theileria species infecting ruminants from Sindh province; however, in Balochistan and FATA, different species Theileria identified from small ruminants include T. annulata, T. ovis and T. lestoquardi $[7,107,116]$. Some studies were carried out in the adjoining areas of two provinces and reported different species of Theileria; for example, in a study Ghafar et al. [128] interestingly identified T. lestoquardi-like spp., T. orientalis and T. annulata 
from the ticks collected from the cattle and buffalo in different agro-ecological zones of Punjab and Sindh Province, while, on the other hand, Durrani et al. [129] and Karim et al. [130] identified T. ovis and T. annulata in small and large ruminants from the different regions of Punjab and Khyber Pakhtunkhwa, respectively.

Table 4. Provincial wise distribution of the different Theileria species in Pakistan.

\begin{tabular}{|c|c|c|c|c|c|}
\hline \multicolumn{6}{|c|}{ Pakistan } \\
\hline Province/State & Theileria Species & Identification Method & Host & Year & Reference \\
\hline \multicolumn{6}{|c|}{ Punjab } \\
\hline \multicolumn{6}{|c|}{ Cattle \& Buffaloes } \\
\hline Punjab & Theileria spp. & Microscopy & Cattle & 1983 & [131] \\
\hline Faisalabad & Theileria spp. & Microscopy & Cattle & 1999 & [132] \\
\hline Faisalabad & T. annulata & Microscopy & Buffaloes \& Cattle & 2004 & [133] \\
\hline Kasur & Theileria spp. & Microscopy & Cattle & 2005 & [134] \\
\hline Punjab & T. annulata & Microscopy & Buffaloes & 2006 & [135] \\
\hline Kasur & T. annulata & Molecular & Cattle & 2008 & [136] \\
\hline Punjab & T. annulata & Microscopy \& Molecular & Cattle & 2008 & [137] \\
\hline Sahiwal & Theileria spp. & Microscopy & Cattle & 2010 & [111] \\
\hline Southern Punjab & T. annulata & Microscopy & Cattle & 2011 & [104] \\
\hline Sargodha & T. annulata & Microscopy & Cattle & 2012 & [138] \\
\hline $\begin{array}{c}\text { Faisalabad, Jhang, } \\
\text { Khanewal }\end{array}$ & T. annulata & Molecular & Ticks of Cattle \& Buffaloes & 2013 & [105] \\
\hline Faisalabad & T. annulata & Molecular & Cattle \& Buffaloes & 2013 & [106] \\
\hline Punjab & T. orientalis & Molecular & Cattle & 2021 & [108] \\
\hline Punjab & T. annulata & Molecular & Cattle & 2018 & [109] \\
\hline Punjab & T. annulata \& T. orientalis & Molecular & Cattle & 2018 & [139] \\
\hline Lahore & T. annulata & Microscopy & Cattle & 2018 & [5] \\
\hline $\begin{array}{c}\text { Agro-ecological Zones } \\
\text { Punjab }\end{array}$ & T. orientalis \& T. annulata & Molecular & Ruminants & 2019 & {$[110]$} \\
\hline $\begin{array}{l}\text { Agro-ecological Zones } \\
\text { Punjab }\end{array}$ & T. annulata & Molecular & Cattle & 2020 & [107] \\
\hline Layyah & T. annulata \& T. orientalis & Molecular & Cattle & 2021 & {$[113]$} \\
\hline $\begin{array}{c}\text { Dera Ghazi Khan \& } \\
\text { Lodhran }\end{array}$ & T. annulata & Molecular & Cattle & 2021 & {$[112]$} \\
\hline Attock & Theileria spp. & Microscopy & Goats \& Sheep & 2010 & [140] \\
\hline Okara & Theileria spp. & Microscopy & Sheep & 2010 & [141] \\
\hline Lahore & T. lestoquardi \& T. ovis & Microscopy \& Molecular & Sheep & 2011 & [142] \\
\hline Lahore & Theileria spp. & Microscopy & Goats \& Sheep & 2011 & [143] \\
\hline Okara & T. ovis & Molecular & Sheep & 2013 & [114] \\
\hline Southern Punjab & T.lestoquardi & Molecular & Goats \& Sheep & 2015 & [144] \\
\hline Multan & T. ovis \& T. lestoquardi & Microscopy \& Molecular & Goats \& Sheep & 2017 & [115] \\
\hline Multan & T. lestoquardi \& T. ovis & Microscopy \& Molecular & Goats \& Sheep & 2017 & [145] \\
\hline Punjab & T. annulata T.ovis \& T. lestoquardi & Molecular & Ruminants & 2019 & [117] \\
\hline Multan & T. lestoquardi E\& T. ovis & Molecular \& Microscopy & Goats & 2019 & [118] \\
\hline Layyah & T. annulata & Molecular & Sheep & 2021 & [119] \\
\hline Lahore & Theileria Spp. & Microscopy & Goats \& Sheep & 2021 & [116] \\
\hline Peshawar & T. annulata & Microscopy & Buffalo \& Cattle & 2005 & [146] \\
\hline KPK (Southern KP) & T. annulata & Molecular & Cattle & 2012 & [147] \\
\hline $\mathrm{KPK}$ & T. annulata & Molecular & Cattle & 2017 & [120] \\
\hline Northern Pakistan & T. annulata & Molecular & Cattle (Ticks) & 2019 & [101] \\
\hline $\begin{array}{c}\text { North-Western } \\
\text { Pakistan }\end{array}$ & T. annulata & Molecular & Cattle & 2021 & [148] \\
\hline DI Khan & Theileria spp. & Microscopy & Cattle & 2021 & [149] \\
\hline Central KPK & T. annulata & Microscopy \& Molecular & Cattle & 2021 & [122] \\
\hline KPK & T. lestoquardi \& T. ovis & Molecular & Goats \& Sheep & 2013 & [147] \\
\hline $\mathrm{KPK}$ & T.lestoquardi & Molecular & Goats \& Sheep & 2015 & [150] \\
\hline Peshawar \& Periphery & Theileria spp. & Microscopy & Ruminants & 2017 & [151] \\
\hline $\begin{array}{c}\text { Peshawar \& Khyber } \\
\text { Agency }\end{array}$ & Theileria & Microscopy & Goats \& Sheep & 2017 & [152] \\
\hline Southern KPK & T. ovis T. lestoquardi & Molecular & Goats \& Sheep & 2018 & {$[123]$} \\
\hline
\end{tabular}


Table 4. Cont.

\begin{tabular}{|c|c|c|c|c|c|}
\hline \multicolumn{6}{|c|}{ Pakistan } \\
\hline Province/State & Theileria Species & Identification Method & Host & Year & Reference \\
\hline Southern KPK & $\begin{array}{l}\text { Theileria spp. } \\
\text { Thnulata }\end{array}$ & Microscopy & Sheep & 2018 & [153] \\
\hline KPK & $\begin{array}{c}\text { T. luwenshuni T. ovis \& } \\
\text { Theileria spp. }\end{array}$ & Molecular & Goats \& Sheep & 2020 & [124] \\
\hline Malakand Division & Theileria spp. & Microscopy & $\begin{array}{l}\text { Buffalo, Cattle, } \\
\text { Goat \& Sheep }\end{array}$ & 2021 & [125] \\
\hline KPK & $\begin{array}{l}\text { Theileria Spp. T. annulata, } \\
\text { T. lestoquardi, T. ovis }\end{array}$ & Molecular & Goats \& Sheep & 2021 & [126] \\
\hline Hyderabad & Theileria spp. & $\begin{array}{l}\text { Sindh } \\
\text { Microscopy }\end{array}$ & Cattle & 1994 & [154] \\
\hline Karachi & Theileria & Microscopy & Buffalo & 2012 & {$[127]$} \\
\hline Quetta & T. annulata & Microscopy & Cattle & 2021 & [116] \\
\hline Baluchistan & Theileria ovis \& T. lestoquardi & Molecular & Goats \& Sheep & 2017 & [7] \\
\hline FATA & T. ovis & Molecular & Goats \& Sheep & 2020 & [107] \\
\hline Punjab \& KPK & T. ovis & Microscopy \& Molecular & Goats \& Sheep & 2012 & [129] \\
\hline Pakistan/Punjab-KPK & T. annulata & Molecular & Ruminants & 2017 & [130] \\
\hline Sindh \& Punjab & $\begin{array}{l}\text { T. lestoquardi-like spp., } \\
\text { T. orientalis \& T. annulata }\end{array}$ & Molecular & Cattle & 2021 & [128] \\
\hline
\end{tabular}

\subsection{Tick Vectors for Transmission of Theileria in Pakistan}

In Pakistan, different studies have reported a wide variety of tick species from various geographical areas as shown in Table 5. In these studies, different tick species have been identified, which may be due to different prevailing conditions in the country such as seasonal fluctuation, relative humidity, temperature, association and lifestyle of different species of animals, lack of education in farmers, and farm management practices which may favor tick growth and survival. In the current study, existence of a wide variety of Theileria species may be due to the presence of different tick vectors, which may possibly play a role in the transmission of these pathogens. Common genera which may be possibly involved in the transmission of these pathogens include Hyalomma, Rhipicephalus and Haemaphysalis. Several studies have reported different tick species across the country such as Hy. hussaini, Hy. scupense, Hy. anatolicum, Hy. scupense, Hy. excavatum, R. microplus, $R$. sanguineus $[105,123,138,155-158]$. These ticks may have the capacity to transmit different Theileria species in different hosts $[103,107]$. However, further molecular studies are needed to find out their vector competencies.

Table 5. Distribution of various tick vectors for the transmission of Theileria species in Pakistan.

\begin{tabular}{|c|c|c|}
\hline Ticks & Host & References \\
\hline $\begin{array}{ll}20 & \text { Punjab }\end{array}$ & & \\
\hline $\begin{array}{r}\text { R. microplus, Hy. anatolicum, Hy. aegyptium, Hy. dromedarii, R. appendiculatus, R. sanguineus } \\
\text { Khyber Pakhtunkhwa }\end{array}$ & Cattle and buffaloes & {$[102,105,138,147,153,157-162]$} \\
\hline R. microplus, $R$. appendiculatus, Hy. anatolicum & Cattle \& buffaloes & {$[101,163]$} \\
\hline Sindh & & \\
\hline $\begin{array}{c}\text { Hy. hussaini, Hy. scupense, R. annulatus, R. microplus, Hy. anatolicum, Hy. scupense, Hy. excavatum } \\
\text { Balochistan }\end{array}$ & Buffaloes & {$[155,156,164]$} \\
\hline R. microplus, Hy. anatolicum, Hy. scupense, Hy. aegyptium, Haemaphysalis & Cattle \& buffaloes & {$[107,165-169]$} \\
\hline $\begin{array}{c}\text { Punjab } \\
\text { Hy. anatolicum, Hy. excavatum R. appendiculatus, Hy. dromedarii, R. microplus, } \\
\text { R. sanguineus, R. Turanicus }\end{array}$ & $\begin{array}{l}\text { Goats } \\
\text { \& Sheep }\end{array}$ & {$[158,160,170-174]$} \\
\hline $\begin{array}{c}\text { Ky. anatolicum, Hy. detritum, Hy. excavatum, Hy. scupense, Haemaphysalis longicornis, Hyalomma } \\
\text { impeltatum, R. appendiculatus, R. microplus }\end{array}$ & Goats \& Sheep & {$[107,175-180]$} \\
\hline $\begin{array}{c}\text { Sindh } \\
\text { Hae. bispinosa, Hy. anatolicum, Hy. detritum, Hy. dromedarii, Hy. hussaini, Hy. impeltatum, } \\
\text { Hy. marginatum isaaci, R. microplus, R. Sanguineus }\end{array}$ & Goats \& Sheep & {$[181,182]$} \\
\hline $\begin{array}{c}\text { Balochistan } \\
\text { Hy. anatolicum, Hy. dromedarii, Hy. excavatum, Hy. scupense, R. microplus }\end{array}$ & Goats \& Sheep & {$[168,183-185]$} \\
\hline
\end{tabular}




\subsection{Regional Wise Distribution of Theileria Species and Its Possible Tick Vectors in Bangladesh}

Different species of Theileria from large and small ruminants from various geographical regions are listed in Table 6. Among these, most of the species such as Theileria spp., T. annulata, T. mutans and T. orientalis have been identified from the large ruminants of Central and North Central regions of Bangladesh [186-189] while, from the Southwestern, Northern and Western region, only Theileria spp. and T. annulata have been reported [190-193]. Furthermore, only one species, i.e., T. annulata, was reported in goats and sheep from the central part of Bangladesh [189,194].

Table 6. Regional wise distribution and diversity of Theileria species in various regions of Bangladesh.

\begin{tabular}{|c|c|c|c|c|c|}
\hline \multicolumn{6}{|c|}{ Bangladesh } \\
\hline City & Theileria spp. & Identification Method & Host & Year of Study & References \\
\hline \multicolumn{6}{|c|}{ Central Region } \\
\hline Dhaka Targil & T. annulata & Microscopy & Cattle & 1983 & [195] \\
\hline Dhaka & T. annulata and T. mutans & Microscopy & Cattle & 1989 & [196] \\
\hline $\begin{array}{c}\text { Dhaka, Sirajganj and } \\
\text { Nikhangsori }\end{array}$ & T. annulata & Microscopy \& Molecular & Cattle goats \& Sheep & 2019 & [194] \\
\hline Dhaka & Theileria spp. & $\begin{array}{c}\text { Goats \& Sheep } \\
\text { Microscopy \& Molecular } \\
\text { South Eastern Region }\end{array}$ & Goats & 2021 & [189] \\
\hline Chittagong & Theileria spp. & $\begin{array}{c}\text { Microscopy } \\
\text { North Central Region }\end{array}$ & Cattle & 2010 & [190] \\
\hline Sirajganj & Theileria spp. & Microscopy & Cattle & 2015 & [187] \\
\hline Sirajganj & T. annulata \& T. mutans & Microscopy & Cattle & 1976 & [186] \\
\hline Sirajganj & T. annulata & Molecular & Cattle & 1977 & [197] \\
\hline Mymensingh & T. orientalis & Molecular & Cattle & 2018 & [188] \\
\hline Dinajpur & Theileria spp. & $\begin{array}{l}\text { Northern Region } \\
\text { Microscopy } \\
\text { Western region }\end{array}$ & Cattle & 2016 & {$[191]$} \\
\hline Rajshahi & T. annulata & Molecular & Cattle & 2016 & [192] \\
\hline Natores & T. annulata & Molecular & Cattle & 2019 & [193] \\
\hline
\end{tabular}

The possible vector tick species from the different geographical places of Bangladesh that could be involved in the transmission of various Theileria species in small and large ruminants are shown in Tables 7 and 8. The common tick species responsible for the transmission of Theileria in cattle and buffalo are R. microplus, Hae. bispinosa, R. sanguineus, and Hy. anatolicum anatolicum [102], while, in the case of small ruminants (goats and sheep), these may be R. sanguineus and Hy. anatolicum anatolicum [102].

Table 7. Distribution of possible tick vectors for Theileria species in various regions of Bangladesh.

\begin{tabular}{|c|c|c|}
\hline Divisions & Possible Tick Vector & Reference \\
\hline Braisel, Dhaka, Savar, Narayanganj, Tangali & R. microplus & [102] \\
\hline Dhaka, Rajshahi, Savar & Hae. bispinosa & [102] \\
\hline North western dry Region (Rajshahi, Rangpur, and Dinajpur districts) & Hy. anatolicum anatolicum & [102] \\
\hline Savar & Hy. Truncatum & [102] \\
\hline Braisal, Chitagang, Dhaka, Narayanganj, Tangail, Rangpur, Sylhet & R. sanguineus & [102] \\
\hline
\end{tabular}

Table 8. Common tick species in different hosts in Bangladesh.

\begin{tabular}{ccc}
\hline Possible Tick Vectors for TT & Host & References \\
\hline R. microplus, Hae. bispinosa, R. sanguineus, Hy. anatolicum anatolicum & Cattle \& Buffaloes & {$[102]$} \\
R. sanguineus, Hy. anatolicum anatolicum & Goats \& Sheep & {$[102]$} \\
\hline
\end{tabular}




\subsection{Phylogenetic Analysis, Genetic Divergence and Multiple Sequence Alignment}

We have selected T. annulata for phylogenetic and genetic divergence analysis as this species may infect all ruminants and could be of great economic concern. The evolutionary history was inferred using an $18 S r R N A$ taxonomic marker. Homology searches of the selected $18 S$ rRNA isolates shared $99-100 \%$ similarities with local and global isolates deposited in the NCBI GenBank. The neighbor-joining algorithm was used to establish a phylogenetic relationship among different selected isolates. The selected $18 \mathrm{~S} r \mathrm{RNA}$ isolates were clustered into different clades (Figure 6). However, no single isolate was selected from Bangladesh as $18 S$ RNA sequence was not available for T. annulata from Bangladesh. We select the $18 \mathrm{~S} r R N A$ genetic marker as several previously published studies used this genetic marker in Pakistan, India and other parts of the world to identify and establish the phylogenetic profile of $T$. annulata circulating in ruminants $[41,101,106,109,198]$. The $18 \mathrm{~S}$ $r R N A$ gene play an important role in genetic variability of Theileria spp. due to the presence of conserved sequences and some hypervariable regions which are crucial in determining the evolutionary patterns and discriminating the various Theileria species $[16,199]$. Furthermore, targeting the amplification of the hypervariable V4 region of the 18S $r R N A$ gene is preferably used for the accurate identification, classification and exploring the population structures of the piroplasm parasites $[117,200]$. Nucleotide sequence heterogeneity analysis (evolutionary/genetic divergence) showed that $T$. annulata isolates were different from each other by $0-4.7 \mathrm{bp}$ as shown in Table 9. Maximum divergence (4.7 bp) was observed with isolates from Pakistan. Additionally, the multiple alignment analysis also showed changes in the nucleotide sequences of different isolates as can be seen in Figure 7. These genetic variations may be due to genetic variability contributed by the deletions, insertions and substitutions in the nucleotide sequences of different isolates [41,55], which may result in the various degrees of pathogenecity and treatment measures in the field. Thus, on the basis of this analysis and previous findings, we concluded that, due to the presence of a hypervariable region and genetic variability, vaccine development against Theileria species is still challenging, and we may suggest that using a single diagnostic or immunogenic molecule may not be sufficient in achieving the required goals.

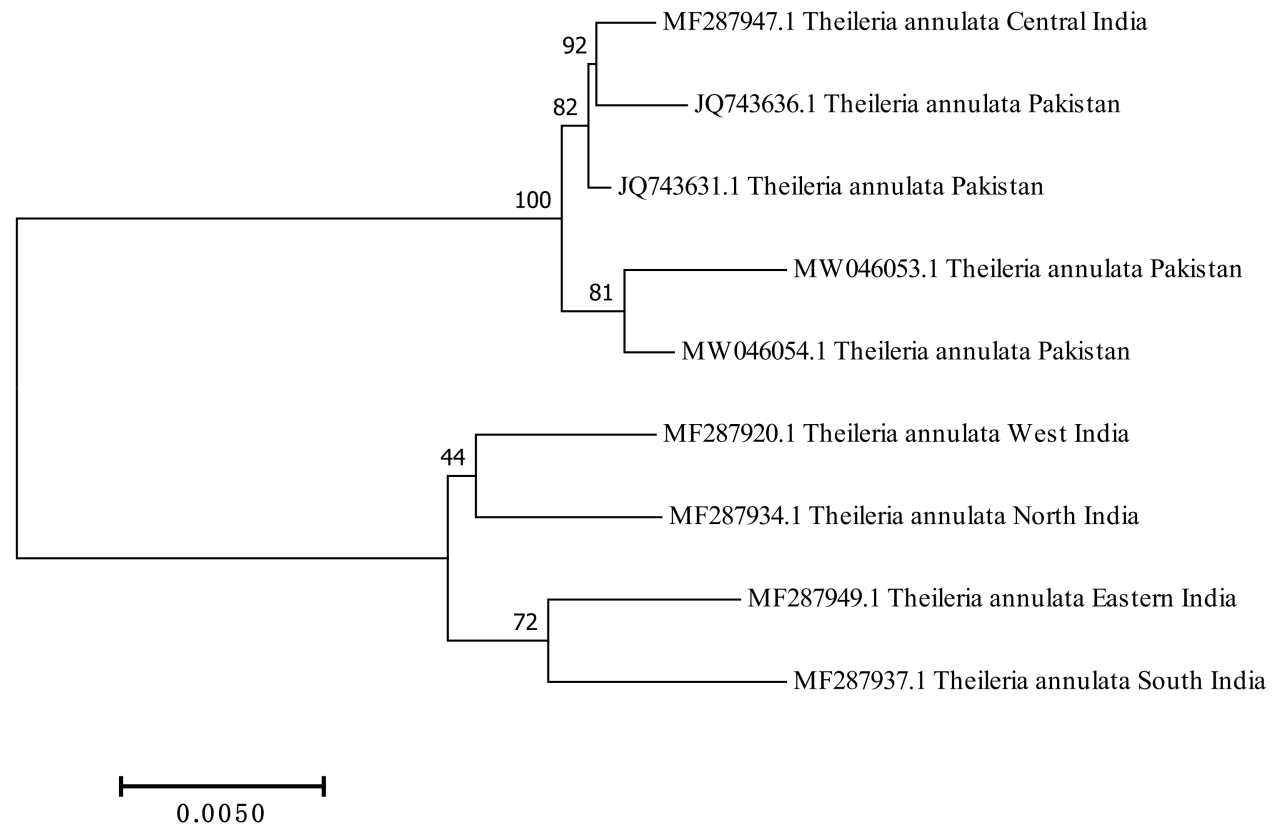

Figure 6. Phylogenetic analysis of selected T. annulata isolates (18 S rRNA gene). 
Table 9. Evolutionary divergence analysis of T. annulata $18 \mathrm{~S} r \mathrm{RNA}$ gene isolates.

\begin{tabular}{|c|c|c|c|c|c|c|c|c|c|}
\hline & 1 & 2 & 3 & 4 & 5 & 6 & 7 & 8 & 9 \\
\hline \multicolumn{10}{|l|}{ MF287947.1 T annulata Central India } \\
\hline MF287920.1 T annulata West India & 0.58 & & & & & & & & \\
\hline MF287949.1 T annulata Eastern India & 0.62 & 0.22 & & & & & & & \\
\hline MF287937.1 T annulata South India & 0.63 & 0.25 & 0.19 & & & & & & \\
\hline MF287934.1 T annulata North India & 0.58 & 0.16 & 0.19 & 0.28 & & & & & \\
\hline JQ743631.1 T annulata Pakistan & 0.4 & 0.55 & 0.59 & 0.6 & 0.56 & & & & \\
\hline JQ743636.1 T annulata Pakistan & 0.7 & 0.6 & 0.63 & 0.065 & 0.6 & 0.5 & & & \\
\hline MW046053.1 T annulata Pakistan & 2.14 & 1.65 & 4.7 & 4.7 & 0.65 & 0.12 & 0.15 & & \\
\hline \multirow[t]{2}{*}{ MW046054.1 T annulata Pakistan } & 0.9 & 0.57 & 2.63 & 3.62 & 0.57 & 3.8 & 0.11 & 0.0 & _ \\
\hline & 1 & 2 & 3 & 4 & 5 & 6 & 7 & 8 & 9 \\
\hline
\end{tabular}

\begin{tabular}{|c|}
\hline Specieg/Abbrv \\
\hline 1. MF287947.1 Theileria annulata_Central_India \\
\hline 2. MF287920.1 Theileria annulata_hest_India \\
\hline 3. MF287949.1 Theileria annulata_Eastern_India \\
\hline 4. MF287937.1 Theileria annulata_South_India \\
\hline 5. MF287934.1 Theileria annulata_North_India \\
\hline 6. JQ743631.1 Theileria annulata_Pakistan \\
\hline 7. J0743636.1 Theileria annulata_Pakistan \\
\hline 8. M046053.1 Theileria annulata_Pakistan \\
\hline 9. Mi046054.1 Theileria annulata_Pakistan \\
\hline
\end{tabular}

Specieg/Abbrv

2. MF287920.1 Theileria annulata_hest_India

3. MF207949.1 Theileria annulata_Eastern_India

5. MF287934.1 Theileria annulata Borth India

6. J0743631.1 Theileria annulata_Pakistan

8. Mn046053.1 Theileria annulata_Pakista

Theileria annulata_Pakista

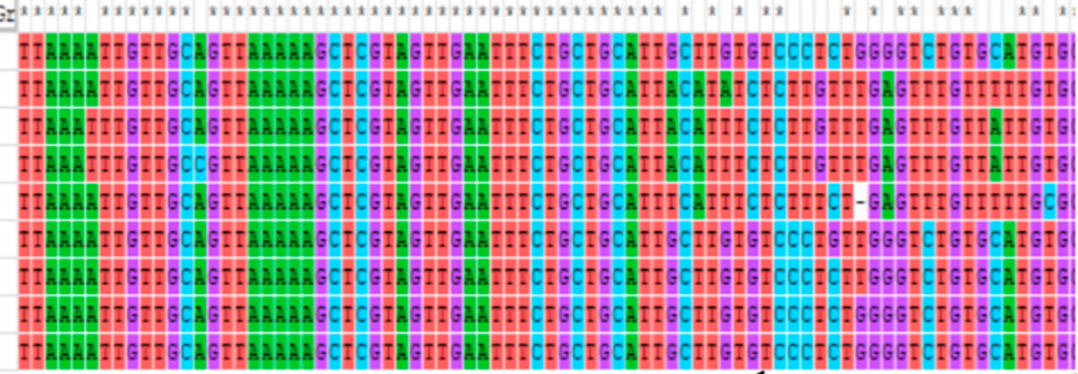

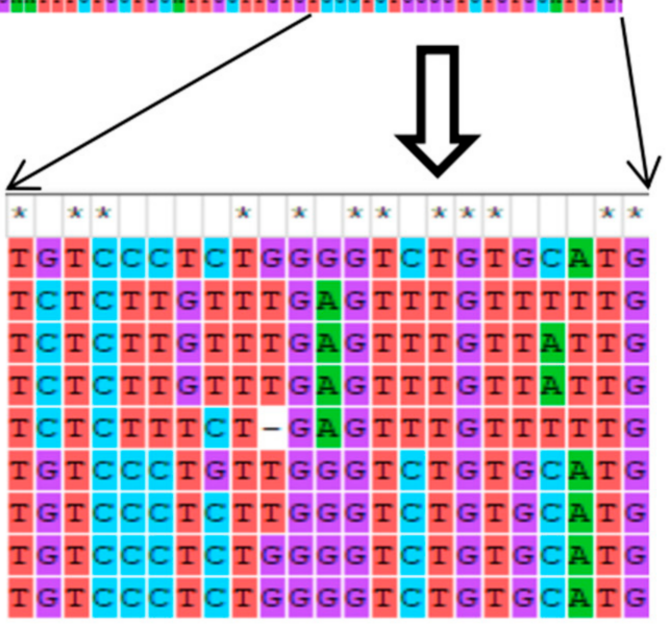

Figure 7. CLUSTAL W multiple sequence alignment analysis for the different T. annulata isolates from India and Pakistan. The box below showing the changes in nucleotide sequences between T. annulata isolates from Pakistan and India. * means nucleotide similarities.

\subsection{Overall Comparison (Why Vector-Borne Diseases like Theileria Are Increasing Day by Day)}

The global climate has been changing over the last century due to greenhouse gas emissions. It will continue to change over this century, accelerating without effective global efforts to reduce emissions. Ticks and tick-borne diseases (TTBDs) are inherently climate-sensitive due to the sensitivity of tick lifecycles to climate. Key direct climate and weather sensitivities include survival of individual ticks and the duration of development and questing (host-seeking) activity of ticks [201].

We have concluded that our data contribute to the knowledge of Theileria species diversity and distribution circulating in ruminants in different regions of India, Pakistan and Bangladesh. The diverse species and wide distribution of Theileria in the region may be linked with the presence of their possible vector tick species belonging to the main four genera including Hyalomma, Haemaphysalis, Rhipicephalus and Amblyomma as they have been identified as Theileria vectors from several parts of the world [101-103,107,117]. Paucity still exists; however, molecular studies have been updated and increased during the last decade regarding Theileria species identification and their possible vectors. Different 
ticks have been adapted to diverse climatic conditions such as aridity in the desert, and seasonal and daily fluctuations may result in widespread distribution of these ticks and subsequently lead to the diversity in Theileria species. This adaptation offers the tick a significant comparative advantage over other tick species under the predicted scenarios for climate change [103], particularly in the context of South Asian countries where these tick species might gain importance in the future. Our analysis suggests the needs of further molecular studies to discover different species and strains, and their potential vectors as microscopic studies have not been so effective in identifying different species and strains. Additionally, genetic variation among different T. annulata isolates may be due to the mutations in the hypervariable region and genetic variability, which makes the therapeutic and single molecule based vaccine development against Theilera challenging and necessitates the needs for alternative control measures. This study also helps in providing a baseline for devising integrated control measures to reduce the losses due to these pathogens being either at the pathogen or vector level.

Thus, on the basis of this analysis and previous findings, we may suggest that using a single diagnostic or immunogenic molecule may not be sufficient in achieving the required goals regarding Theileria control strategies.

Author Contributions: J.Z. designed the study, searched the literature, identified and screened articles, and extracted data which was reviewed by O.S., J.Z., B.S., S.H. and M.U.A. wrote the first draft of the manuscript. J.Z. performed molecular and genetic analysis. R.Z. conducted geographic and regional analysis of data. O.S. revised the manuscript critically. All the authors approved the final version of the manuscript. All authors have read and agreed to the published version of the manuscript.

Funding: O.S. is a Principal Investigator of an internal research fund of the Department of Infectious Diseases and Public Health of the City University of Hong Kong (Project number 9380108).

Institutional Review Board Statement: Not applicable.

Informed Consent Statement: Not applicable.

Acknowledgments: We are thankful to all authors whose articles are included in this study.

Conflicts of Interest: The authors declare that there is no conflict of interest.

\section{References}

1. Lew-Tabor, A.E.; Valle, M.R. A review of reverse vaccinology approaches for the development of vaccines against ticks and tick borne diseases. Ticks Tick-Borne Dis. 2016, 7, 573-585. [CrossRef]

2. Nene, V.; Kiara, H.; Lacasta, A.; Pelle, R.; Svitek, N.; Steinaa, L. The biology of Theileria parva and control of East Coast fever-current status and future trends. Ticks Tick-Borne Dis. 2016, 7, 549-564. [CrossRef]

3. Ica, A.; Vatansever, Z.; Yildirim, A.; Duzlu, O.; Inci, A. Detection of Theileria and Babesia species in ticks collected from cattle. Vet. Parasitol. 2007, 148, 156-160. [CrossRef]

4. Jenkins, C. Bovine theileriosis in Australia: A decade of disease. Microbiol. Aust. 2018, 39, 215-219. [CrossRef]

5. Rashid, M.; Akbar, H.; Rashid, I.; Saeed, K.; Ahmad, L.; Ahmad, A.S.; Shehzad, W.; Islam, S.; Farooqi, S. Economic significance of tropical theileriosis on a Holstein Friesian dairy farm in Pakistan. J. Parasitol. 2018, 104, 310-312. [CrossRef]

6. Gul, N.; Ayaz, S.; Gul, I.; Adnan, M.; Shams, S.; Akbar, N. Tropical theileriosis and east coast fever in cattle: Present, past and future perspective. Int. J. Curr. Microbiol. Appl. Sci. 2015, 4, 1000-1018.

7. Khan, M.A.; Khan, M.; Ahmad, I.; Khan, M.; Anjum, A.; Durrani, A.; Hameed, K.; Kakar, I.; Wajid, A.; Ramazan, M. Risk factors assessment and molecular characterization of Theileria in small ruminants of Balochistan. J. Anim. Plant Sci. 2017, 27, 1190-1196.

8. Shaw, M.K.; Tilney, L.G. How individual cells develop from a syncytium: Merogony in Theileria parva (Apicomplexa). J. Cell Sci. 1992, 101, 109-123. [CrossRef]

9. Bishop, R.; Musoke, A.; Morzaria, S.; Gardner, M.; Nene, V. Theileria: Intracellular protozoan parasites of wild and domestic ruminants transmitted by ixodid ticks. Parasitology 2004, 129, S271-S283. [CrossRef]

10. Dobbelaere, D.; Heussler, V. Transformation of Leukocytes by Theileria parva and T. annulata. Annu. Rev. Microbiol. 1999, 53, 1-42. [CrossRef]

11. Conrad, P.A.; Denham, D.; Brown, C.G.D. Intraerythrocytic multiplication of Theileria parva in vitro: An ultrastructural study. Int. J. Parasitol. 1986, 16, 223-229. [CrossRef]

12. Kawamoto, S.; Takahashi, K.; Kurosawa, T.; Sonoda, M.; Onuma, M. Intraerythrocytic schizogony of Theileria sergenti in cattle. Jpn. J. Vet. Sci. 1990, 52, 1251-1259. [CrossRef] [PubMed] 
13. Katzer, F.; Ngugi, D.; Oura, C.; Bishop, R.P.; Taracha, E.L.N.; Walker, A.R.; McKeever, D.J. Extensive genotypic diversity in a recombining population of the apicomplexan parasite Theileria parva. Infect. Immun. 2006, 74, 5456-5464. [CrossRef] [PubMed]

14. Weir, W.; Ben-Miled, L.; Karagenç, T.; Katzer, F.; Darghouth, M.; Shiels, B.; Tait, A. Genetic exchange and sub-structuring in Theileria annulata populations. Mol. Biochem. Parasitol. 2007, 154, 170-180. [CrossRef] [PubMed]

15. OIE. THEILERIOSIS Aetiology Epidemiology Diagnosis Prevention and Control References; OIE: Paris, France, 2021. Available online: https: / / www.oie.int/app/uploads/2021/03/theileriosis.pdf (accessed on 26 December 2021).

16. Sivakumar, T.; Hayashida, K.; Sugimoto, C.; Yokoyama, N. Evolution and genetic diversity of Theileria. Infect. Genet. Evol. 2014, 27, 250-263. [CrossRef]

17. Böse, R.; Jorgensen, W.K.; Dalgliesh, R.J.; Friedhoff, K.T.; De Vos, A.J. Current state and future trends in the diagnosis of babesiosis. Vet. Parasitol. 1995, 57, 61-74. [CrossRef]

18. Passos, L.M.F.; Bell-Sakyi, L.; Brown, C.G.D. Immunochemical characterization of in vitro culture-derived antigens of Babesia bovis and Babesia bigemina. Vet. Parasitol. 1998, 76, 239-249. [CrossRef]

19. Gubbels, J.M.; De Vos, A.P.; Van der Weide, M.; Viseras, J.; Schouls, L.M.; De Vries, E.; Jongejan, F. Simultaneous detection of bovine Theileria and Babesia species by reverse line blot hybridization. J. Clin. Microbiol. 1999, 37, 1782-1789. [CrossRef]

20. Rougemont, M.; Van Saanen, M.; Sahli, R.; Hinrikson, H.P.; Bille, J.; Jaton, K. Detection of four Plasmodium species in blood from humans by $18 \mathrm{~S}$ rRNA gene subunit-based and species-specific real-time PCR assays. J. Clin. Microbiol. 2004, 42, 5636-5643. [CrossRef]

21. Mens, P.F.; Schoone, G.J.; Kager, P.A.; Schallig, H.D.F.H. Detection and identification of human Plasmodium species with real-time quantitative nucleic acid sequence-based amplification. Malar. J. 2006, 5, 80. [CrossRef]

22. Steenkeste, N.; Incardona, S.; Chy, S.; Duval, L.; Ekala, M.-T.; Lim, P.; Hewitt, S.; Sochantha, T.; Socheat, D.; Rogier, C. Towards high-throughput molecular detection of Plasmodium: New approaches and molecular markers. Malar. J. 2009, 8, 86. [CrossRef] [PubMed]

23. Agudelo, O.; Arango, E.; Maestre, A.; Carmona-Fonseca, J. Prevalence of gestational, placental and congenital malaria in north-west Colombia. Malar. J. 2013, 12, 341. [CrossRef] [PubMed]

24. Haanshuus, C.G.; Mohn, S.C.; Mørch, K.; Langeland, N.; Blomberg, B.; Hanevik, K. A novel, single-amplification PCR targeting mitochondrial genome highly sensitive and specific in diagnosing malaria among returned travellers in Bergen, Norway. Malar. J. 2013, 12, 26. [CrossRef] [PubMed]

25. Lee, Y.-H.; Lai, Y.-H. Fabrication and Characterization of HER2 Cell Receptor-Targeted Indocyanine Green-Encapsulated Poly (Lactic-co-Glycolic Acid) Nanoparticles. Peertechz J. Biomed. Eng. 2015, 1, 15-20.

26. Bilgiç, H.B.; Karagenç, T.; Simuunza, M.; Shiels, B.; Tait, A.; Eren, H.; Weir, W. Development of a multiplex PCR assay for simultaneous detection of Theileria annulata, Babesia bovis and Anaplasma marginale in cattle. Exp. Parasitol. 2013, 133, $222-229$. [CrossRef]

27. Chaisi, M.E.; Janssens, M.E.; Vermeiren, L.; Oosthuizen, M.C.; Collins, N.E.; Geysen, D. Evaluation of a Real-Time PCR Test for the Detection and Discrimination of Theileria Species in the African Buffalo (Syncerus caffer). PLoS ONE 2013, 8, e75827. [CrossRef]

28. Kundave, V.R.; Ram, H.; Banerjee, P.S.; Garg, R.; Mahendran, K.; Ravikumar, G.; Tiwari, A.K. Development of multiplex PCR assay for concurrent detection of tick borne haemoparasitic infections in bovines. Acta Parasitol. 2018, 63, 759-765. [CrossRef]

29. Ayadi, O.; Gharbi, M.; Elfegoun, M.C.B. Milk losses due to bovine tropical theileriosis (Theileria annulata infection) in Algeria. Asian Pac. J. Trop. Biomed. 2016, 6, 801-802. [CrossRef]

30. Kerario, I.I.; Simuunza, M.; Laisser, E.L.K.; Chenyambuga, S. Exploring knowledge and management practices on ticks and tick-borne diseases among agro-pastoral communities in Southern Highlands, Tanzania. Vet. World 2018, 11, 48. [CrossRef]

31. Elsheikha, H. Management of ticks and tick-borne diseases: Challenges and opportunities. Vet. Nurse 2019, 10, 60-63. [CrossRef]

32. Kumar, S.; Stecher, G.; Tamura, K. MEGA7: Molecular evolutionary genetics analysis version 7.0 for bigger datasets. Mol. Biol. Evol. 2016, 33, 1870-1874. [CrossRef]

33. Sangwan, A.K.; Chhabra, M.B.; Samantaray, S. Relative role of male and female Hyalomma anatolicum anatolicum ticks in Theileria transmission. Vet. Parasitol. 1989, 31, 83-87. [CrossRef]

34. Naik, B.S.; Maiti, S.K.; Raghuvanshi, P.D.S. Prevalence of tropical theileriosis in cattle in Chhattisgarh State. J. Anim. Res. 2016, 6 , 1043-1045. [CrossRef]

35. Das, G.; Ray, D. PCR-based detection of Theileria annulata infection in ticks collected from cattle of West Bangal, India. J. Vet. Parasitol. 2003, 17, 11-14.

36. Kartashov, M.Y.; Naidenova, E.V.; Zakharov, K.S.; Yakovlev, S.A.; Skarnovich, M.O.; Boumbaly, S.; Nikiforov, K.A.; Plekhanov, N.A.; Kritzkiy, A.A.; Ternovoi, V.A. Detection of Babesia caballi, Theileria mutans and Th. velifera in ixodid ticks collected from cattle in Guinea in 2017-2018. Vet. Parasitol. Reg. Stud. Rep. 2021, 24, 100564. [CrossRef]

37. Ananda, K.J.; D’Souza, P.E.; Puttalakshmamma, G.C. Prevalence of Haemoprotozoan diseases in crossbred cattle in Banglore north. Vet. World 2009, 2, 15. [CrossRef]

38. Nair, A.S.; Ravindran, R.; Lakshmanan, B.; Kumar, S.S.; Tresamol, P.V.; Saseendranath, M.R.; Senthilvel, K.; Rao, J.R.; Tewari, A.K.; Ghosh, S. Haemoprotozoa of cattle in northern Kerala, India. Trop. Biomed. 2011, 28, 68-75.

39. Maharana, B.R.; Kumar, B.; Prasad, A.; Patbandha, T.K.; Sudhakar, N.R.; Joseph, J.P.; Patel, B.R. Prevalence and assessment of risk factors for haemoprotozoan infections in cattle and buffaloes of South-West Gujarat, India. Indian J. Anim. Res. 2016, 50, 733-739. 
40. Aparna, M.; Vimalkumar, M.B.; Varghese, S.; Senthilvel, K.; Ajithkumar, K.G.; Raji, K.; Syamala, K.; Priya, M.N.; Deepa, C.K.; Jyothimol, G. Phylogenetic analysis of bovine Theileria spp. isolated in south India. Trop. Biomed. 2013, 30, $281-290$.

41. George, N.; Bhandari, V.; Reddy, D.P.; Sharma, P. Emergence of new genotype and diversity of Theileria orientalis parasites from bovines in India. Infect. Genet. Evol. 2015, 36, 27-34. [CrossRef]

42. Ananda, K.J.; Adeppa, J. Prevalence of Haemoprotozoan infections in bovines of Shimoga region of Karnataka state. J. Parasit. Dis. 2016, 40, 890-892.

43. Nimisha, M.; Devassy, J.K.; Pradeep, R.K.; Pakideery, V.; Sruthi, M.K.; Pious, A.; Kurbet, P.S.; Amrutha, B.M.; Chandrasekhar, L.; Deepa, C.K. Ticks and accompanying pathogens of domestic and wild animals of Kerala, South India. Exp. Appl. Acarol. 2019, 79, 137-155. [CrossRef] [PubMed]

44. Selim, A.M.; Das, M.; Senapati, S.K.; Jena, G.R.; Mishra, C.; Mohanty, B.; Panda, S.K. Transplacental transmission of Theileria annulata in cattle confirmed by molecular techniques. J. Parasit. Dis. 2021, 45, 336-340. [CrossRef] [PubMed]

45. Dehuri, M.; Panda, M.; Sahoo, N.; Mohanty, B.; Behera, B. Nested PCR assay for detection of Theileria annulata in Hyalomma anatolicum infesting cattle from coastal Odisha, India. Anim. Biotechnol. 2021, 1-6. [CrossRef] [PubMed]

46. Banerji, P.K.; Samaddar, J.; Gupta, R.; Paul, J.; Guha, C. Natural infection with Theileria hirci in Jumnapari goat-A case report. Indian Vet. J. 1990, 67, 677-678.

47. Shruthi, R.; Thimmareddy, P.M.; Mamatha, G.S.; Chandranaik, B.M.; Puttalakshmamma, G.C. Studies on theileriosis in goats from Karnataka, South India. J. Parasit. Dis. 2017, 41, 1082-1085. [CrossRef]

48. Mamatha, G.S.; Shruthi, R.; Chandranaik, B.M.; D'Souza, P.E.; Thimmareddy, P.M.; Shivashankar, B.P.; Puttalakshmamma, G.C. Molecular epidemiology and phylogenetic characterisation of Theileria luwenshuni in India: A first report. Small Rumin. Res. 2017, 154, 52-57. [CrossRef]

49. Begam, R.; Talukdar, S.K.; Sarmah, P.C.; Bulbul, K.H.; Kakati, P.; Tamuly, S.; Islam, S. Molecular and microscopic detection of Theileria luwenshuni infection in goats in and around Guwahati of Assam, India. Biol. Rhythm Res. 2019, 1-8. [CrossRef]

50. Begam, R.; Talukdar, S.; Sarmah, P.C.; Bulbul, K.H.; Kakati, P.; Neog, R.; Saleque, A.; Tamuly, S.; Tamuli, S.M. Emergence of Theileria luwenshuni infection in goats of Assam, India. J. Entomol. Zool. Stud. 2018, 6, 100.

51. Bhosale, A.A.; Bhikane, A.U.; Chavhan, S.G.; Jadhav, R.K.; Mohan, A.; Kushwaha, N. Prevalence and Clinico-Therapeutic Management of Bubaline Theileriosis in Marathwada Region of Maharashtra. Int. J. Livest. Res. 2020, 10, 155-165. [CrossRef]

52. Kundave, V.R.; Patel, A.K.; Patel, P.V.; Hasnani, J.J.; Joshi, C.G. Qualitative and quantitative assessment of Theileria annulata in cattle and buffaloes Polymerase Chain Reaction. Trop. Biomed. 2014, 31, 728-735. [PubMed]

53. Kundave, V.R.; Patel, A.K.; Patel, P.V.; Hasnani, J.J.; Joshi, C.G. Detection of theileriosis in cattle and buffaloes by polymerase chain reaction. J. Parasit. Dis. 2015, 39, 508-513. [CrossRef] [PubMed]

54. Chauhan, H.C.; Patel, B.K.; Bhagat, A.G.; Patel, M.V.; Patel, S.I.; Raval, S.H.; Panchasara, H.H.; Shrimali, M.D.; Patel, A.C.; Chandel, B.S. Comparison of molecular and microscopic technique for detection of Theileria annulata from the field cases of cattle. Vet. World 2015, 8, 1370-1374. [CrossRef] [PubMed]

55. Kundave, V.R.; Ram, H.; Shahzad, M.; Garg, R.; Banerjee, P.S.; Nehra, A.K.; Rafiqi, S.I.; Ravikumar, G.; Tiwari, A.K. Genetic characterization of Theileria species infecting bovines in India. Infect. Genet. Evol. 2019, 75, 103962. [CrossRef] [PubMed]

56. Larcombe, S.D.; Kolte, S.W.; Ponnudurai, G.; Kurkure, N.; Magar, S.; Velusamy, R.; Rani, N.; Rubinibala, B.; Rekha, B.; Alagesan, A. The impact of tick-borne pathogen infection in Indian bovines is determined by host type but not the genotype of Theileria annulata. Infect. Genet. Evol. 2019, 75, 103972. [CrossRef]

57. Azhahianambi, P.; Madhanmohan, M.; Madan, N.; Kumaran, D.; Priyadharshini, M.L.M.; Bharathi, R.; Senthilkumar, T.M.A.; Manoharan, S. Successful treatment of severe form of bovine tropical theileriosis in dairy cattle and genotyping of Theileria annulata isolates of Tamil Nadu, India. Vet. Parasitol. Reg. Stud. Rep. 2021, 26, 100628. [CrossRef]

58. Kolte, S.W.; Larcombe, S.D.; Jadhao, S.G.; Magar, S.P.; Warthi, G.; Kurkure, N.V.; Glass, E.J.; Shiels, B.R. PCR diagnosis of tick-borne pathogens in Maharashtra state, India indicates fitness cost associated with carrier infections is greater for crossbreed than native cattle breeds. PLoS ONE 2017, 12, e0174595. [CrossRef]

59. Manuja, A.; Malhotra, D.V.; Sikka, V.K.; Sangwan, A.K.; Sharma, R.; Kumar, B.; Mehta, B.D.; Gulati, B.R.; Nichani, A.K. Isolates of Theileria annulata collected from different parts of India show phenotypic and genetic diversity. Vet. Parasitol. 2006, 137, 242-252. [CrossRef]

60. Velusamy, R.; Rani, N.; Ponnudurai, G.; Anbarasi, P. Prevalence of intestinal and haemoprotozoan parasites of small ruminants in Tamil Nadu, India. Vet. World 2015, 8, 1205. [CrossRef]

61. Jayaram, A.S.; Soundararajan, C.; Latha, B.R.; Senthilkumar, T.M.A. Molecular detection of Theileria Luwenshuni in sheep and goats of Chennai, Tamil Nadu. Indian J. Small Rumin. 2019, 25, 242-246. [CrossRef]

62. Dhaygude, V.S.; Kundu, K.; Kamdi, B.P.; Bagal, U.R.; Bhosale, S.B.; Sabharwal, D. Investigations on first confirmed outbreak of ovine theileriosis (Theileria luwenshuni) from Maharashtra state, India. Indian J. Anim. Res. 2021, 55, 951-955. [CrossRef]

63. Devi, G.; Ajith, Y.; Mal, G.; Dimri, U.; Preena, P.; Jairath, G.; Kattoor, J.J.; Jacob, S.S.; Singh, B.; Dhar, J.B. Migratory Gaddi sheep and goats as potential carriers of Theileria infection: A molecular survey. Trop. Anim. Health Prod. 2021, 53, 302. [CrossRef] [PubMed]

64. Bhattacharyulu, Y.; Chaudhri, R.P.; Gill, B.S. Transstadial transmission of Theileria annulata through common ixodid ticks infesting Indian cattle. Parasitology 1975, 71, 1-7. [CrossRef] [PubMed] 
65. Srivastava, P.S.; Sharma, N.N. Potential of immunoprophylaxis using cobalt-60 irradiated Theileria annulata in salivary gland suspensions of the tick Hyalomma anatolicum. Vet. Parasitol. 1977, 3, 183-188. [CrossRef]

66. Sudan, V.; Sharma, R.L.; Yadav, R.; Borah, M.K. Turning sickness in a cross bred cow naturally infected with Theileria annulata. J. Parasit. Dis. 2012, 36, 226-229. [CrossRef]

67. Sudan, V.; Singh, S.K.; Jaiswal, A.K.; Parashar, R.; Shanker, D. First molecular evidence of the transplacental transmission of Theileria annulata. Trop. Anim. Health Prod. 2015, 47, 1213-1215. [CrossRef]

68. Kumar, A.; Gaur, G.K.; Gandham, R.K.; Panigrahi, M.; Ghosh, S.; Saravanan, B.C.; Bhushan, B.; Tiwari, A.K.; Sulabh, S.; Priya, B. Global gene expression profile of peripheral blood mononuclear cells challenged with Theileria annulata in crossbred and indigenous cattle. Infect. Genet. Evol. 2017, 47, 9-18. [CrossRef]

69. Mohmad, A.; Chandra, D.; Saravanan, B.C.; Manjunathchar, H.V.; OR, V.K.; Fular, A.; Chigure, G.; Kaur, N.; Ghosh, S. Development of a recombinant TaSP-based Dot-ELISA for detection of Theileria annulata infection in cattle. Ticks Tick. Borne. Dis. 2018, 9 , 1416-1420. [CrossRef]

70. Aparna, M.; Ravindran, R.; Vimalkumar, M.B.; Lakshmanan, B.; Rameshkumar, P.; Kumar, K.G.A.; Promod, K.; Ajithkumar, S.; Ravishankar, C.; Devada, K. Molecular characterization of Theileria orientalis causing fatal infection in crossbred adult bovines of South India. Parasitol. Int. 2011, 60, 524-529. [CrossRef]

71. Velusamy, R.; Rani, N.; Ponnudurai, G.; Harikrishnan, T.J.; Anna, T.; Arunachalam, K.; Senthilvel, K.; Anbarasi, P. Influence of season, age and breed on prevalence of haemoprotozoan diseases in cattle of Tamil Nadu, India. Vet. World 2014, 7, 574-578. [CrossRef]

72. Dharanesha, N.K.; Giridhar, P.; Byregowda, S.M.; Venkatesh, M.D.; Ananda, K.J. Seasonal prevalence of blood parasitic diseases in crossbred cattle of Mysore and its surrounding districts of Karnataka. J. Parasit. Dis. 2017, 41, 773-777. [CrossRef] [PubMed]

73. Krishnamoorthy, P.; Sudhagar, S.; Goudar, A.L.; Jacob, S.S.; Suresh, K.P. Molecular survey and phylogenetic analysis of tick-borne pathogens in ticks infesting cattle from two South Indian states. Vet. Parasitol. Reg. Stud. Rep. 2021, 25, 100595. [CrossRef] [PubMed]

74. Srinivas, R.P.; Renukaprasad, C.; Keshvamurthy, B.S. A note on occurrence of outbreak of theileriosis in sheep in Karnataka Indian J. Comp. Microbiol. Immunol. Infect. Dis. 1985, 6, 165-166.

75. Hitaishi, V.N.; Lakshmanan, B.; Shameem, H.; Jose, P.E.; Jain Jose, K.; Sabu, L. Molecular identification of theileriosis in goats of Kerala. Int. J. Sci. Environ. Technol. 2017, 6, 1979-1984.

76. Biradar, S.S.; D'Souza, P.E.; Mamatha, G.S.; Yathish, H.M.; Siju, S.J. Molecular epidemiology and phylogenetic analysis of Theileria species in sheep. Indian J. Small Rumin. 2019, 25, 192-198. [CrossRef]

77. Satbige, A.S.; Patil, N.A. Therapeutic Management of Theileriosis in Sheep. Int. J. Livest. Res. 2020, 10, 168-170. [CrossRef]

78. Kakati, P.; Sarmah, P.C.; Ray, D.; Bhattacharjee, K.; Sharma, R.K.; Barkalita, L.M.; Sarma, D.K.; Baishya, B.C.; Borah, P.; Stanley, B. Emergence of oriental theileriosis in cattle and its transmission through Rhipicephalus (Boophilus) microplus in Assam, India. Vet. World 2015, 8, 1099. [CrossRef] [PubMed]

79. Sahoo, N.; Behera, B.K.; Khuntia, H.K.; Dash, M. Prevalence of carrier state theileriosis in lactating cows. Vet. World $2017,10,1471$. [CrossRef]

80. Acharya, A.P.; Panda, S.K.; Prusty, B.K. Diagnosis and confirmation of Theileria annulata infection in cattle in Odisha, India. J. Entomol. Zool. Stud. 2017, 5, 1543-1546.

81. Selim, A.M.; Senapati, S.K.; Das, M.; Mishra, C.; Patra, R.C.; Panda, S.K. Molecular, epidemiological and haematological evaluation in Theileria orientalis infected cattle from an endemic region in India. Anim. Biotechnol. 2020, 32, 663-670. [CrossRef]

82. Kala, S.; Gopal Deo, B.; Kumari, N. Prevalence of Theileriosis in Buffaloes during Rainy Season in and Around Patna, Bihar. Int. J. Curr. Microbiol. Appl. Sci. 2018, 7, 2762-2766. [CrossRef]

83. Roy, S.; Bhandari, V.; Dandasena, D.; Murthy, S.; Sharma, P. Genetic profiling reveals high allelic diversity, heterozygosity and antigenic diversity in the clinical isolates of the Theileria annulata from India. Front. Physiol. 2019, 10, 673. [CrossRef] [PubMed]

84. Sinha, B.S.; Sarkar, S.; Lodh, C.; Gupta, A.R.; Batabyal, S.; Jas, R. Prevalence of Bovine Theileriosis in South Bihar. Pharma Innov. J. 2021, SP-10, 776-780.

85. Prabhakaran, H.S.; Ghosh, K.K.; Kumari, R.R.; Kumar, P.; Kumar, M. Evaluation of sporozoite and macroschizont antigen (Spm2) of Theileria annulata for its diagnostic potential. Ticks Tick-Borne Dis. 2021, 12, 101691. [CrossRef] [PubMed]

86. Sharma, G.; Sharma, R.D.; Nichani, A.K. Successful long-term in vitro cultivation of Theileria annulata schizonts in media supplemented with homologous and heterologous sera. Vet. Parasitol. 1998, 79, 135-141. [CrossRef]

87. Govindarajan, R.; Pazhanivel, N.; Sunder, N.; Sekar, M.; Jawahar, T.P.; Purusothaman, V. An outbreak of concurrent infection of theileriosis and sheep pox in Tamil Nadu, India. Indian J. Anim. Sci. 2005, 75, 787-788.

88. Haque, M.; Singh, N.K.; Rath, S.S. Prevalence of Theileria annulata infection in Hyalomma anatolicum anatolicum in Punjab state, India. J. Parasit. Dis. 2010, 34, 48-51. [CrossRef]

89. Vahora, S.P.; Patel, J.V.; Patel, B.B.; Patel, S.B.; Umale, R.H. Seasonal incidence of Haemoprotozoal diseases in crossbred cattle and buffalo in Kaira and Anand districts of Gujarat, India. Vet. World 2012, 5, 223. [CrossRef]

90. Singh, N.K.; Singh, H.; Haque, M.; Rath, S.S. Prevalence of parasitic infections in cattle of Ludhiana district, Punjab. J. Parasit. Dis. 2012, 36, 256-259. [CrossRef]

91. Tuli, A.; Das Singla, L.; Sharma, A.; Bal, M.S.; Filia, G.; Kaur, P. Molecular epidemiology, risk factors and hematochemical alterations induced by Theileria annulata in bovines of Punjab (India). Acta Parasitol. 2015, 60, 378-390. [CrossRef] 
92. Tiwari, A.; Singh, N.K.; Singh, H.; Bhat, S.A.; Rath, S.S. Prevalence of Theileria annulata infection in Hyalomma anatolicum anatolicum collected from crossbred cattle of Ludhiana, Punjab. J. Parasit. Dis. 2015, 39, 57-61. [CrossRef]

93. Bhatnagar, C.S.; Bhardawaj, B.; Sharma, D.K.; Meena, S.K. Incidence of Haemoprotozoan diseases in cattle in Southern Rajasthan, India. Int. J. Curr. Microbiol. Appl. Sci. 2015, 4, 509-514.

94. Afifi, N.A.; Shihata, I.M.; El-Zorba, H.Y.; Ismail, I.M. Prevalence of theileriosis in cross-bred cattle: Its detection through blood smear examination and polymerase chain reaction in Dehradun district, Uttarakhand, India. Vet. World 2014, 7, 168.

95. Ganguly, A.; Bisla, R.S.; Singh, H.; Bhanot, V.; Kumar, A.; Kumari, S.; Maharana, B.R.; Ganguly, I. Prevalence and haematobiochemical changes of tick borne haemoparasitic diseases in crossbred cattle of Haryana, India. Indian J. Anim. Sci. 2017, 87, 552-557.

96. Ganguly, A.; Maharana, B.R.; Ganguly, I. Pentaplex PCR assay for rapid differential detection of Babesia bigemina, Theileria annulata, Anaplasma marginale and Trypanosoma evansi in cattle. Biologicals 2020, 63, 81-88. [CrossRef] [PubMed]

97. Kundave, V.R.; Nehra, A.K.; Ram, H.; Kumari, A.; Shahzad, M.; Vinay, T.S.; Garg, R.; Banerjee, P.S.; Singh, G.; Tiwari, A.K. Genetic diversity in the Tams1 gene of Theileria annulata (Duschunkowsky and Luhs, 1904) infecting cattle. Acta Trop. $2021,224,106121$.

98. Patial, V.; Gupta, T.; Angaria, S.; Bali, D.; Katoch, A.; Gautam, M.; Singh, N.K.; Sharma, M.; Chahota, R. Theileria orientalis outbreak in an organized cattle breeding farm. Vet. Parasitol. Reg. Stud. Rep. 2021, 24, 100572. [CrossRef]

99. Kamau, J.; de Vos, A.J.; Playford, M.; Salim, B.; Kinyanjui, P.; Sugimoto, C. Emergence of new types of Theileria orientalis in Australian cattle and possible cause of theileriosis outbreaks. Parasit. Vectors 2011, 4, 22.

100. Jongejan, F.; Uilenberg, G. The global importance of ticks. Parasitology 2004, 129, S3-S14. [CrossRef] [PubMed]

101. Zeb, J.; Szekeres, S.; Takács, N.; Kontschán, J.; Shams, S.; Ayaz, S.; Hornok, S. Genetic diversity, piroplasms and trypanosomes in Rhipicephalus microplus and Hyalomma anatolicum collected from cattle in northern Pakistan. Exp. Appl. Acarol. 2019, 79, 233-243. [CrossRef]

102. Ghosh, S.; Bansal, G.C.; Gupta, S.C.; Ray, D.; Khan, M.Q.; Irshad, H.; Shahiduzzaman, M.D.; Seitzer, U.; Ahmed, J.S. Status of tick distribution in Bangladesh, India and Pakistan. Parasitol. Res. 2007, 101, 207-216. [CrossRef] [PubMed]

103. Gharbi, M.; Darghouth, M.A.; Elati, K.; AL-Hosary, A.A.T.; Ayadi, O.; Salih, D.A.; El Hussein, A.M.; Mhadhbi, M.; Khamassi Khbou, M.; Hassan, S.M.; et al. Current status of tropical theileriosis in Northern Africa: A review of recent epidemiological investigations and implications for control. Transbound. Emerg. Dis. 2020, 67, 8-25. [CrossRef] [PubMed]

104. Shahnawaz, S.; Ali, M.; Aslam, M.A.; Fatima, R.; Chaudhry, Z.I.; Hassan, M.U.; Iqbal, F. A study on the prevalence of a ticktransmitted pathogen, Theileria annulata, and hematological profile of cattle from Southern Punjab (Pakistan). Parasitol. Res. 2011, 109, 1155-1160. [CrossRef] [PubMed]

105. Ali, Z.; Maqbool, A.; Muhammad, K.; Khan, M.; Younis, M. Prevalence of Theileria annulata infected hard ticks of cattle and buffalo in Punjab, Pakistan. DNA 2013, 862, 846.

106. Khan, M.K.; He, L.; Hussain, A.; Azam, S.; Zhang, W.-J.; Wang, L.-X.; Zhang, Q.-L.; Hu, M.; Zhou, Y.-Q.; Zhao, J. Molecular epidemiology of Theileria annulata and identification of $18 \mathrm{~S}$ rRNA gene and ITS regions sequences variants in apparently healthy buffaloes and cattle in Pakistan. Infect. Genet. Evol. 2013, 13, 124-132. [CrossRef]

107. Ghafar, A.; Cabezas-Cruz, A.; Galon, C.; Obregon, D.; Gasser, R.B.; Moutailler, S.; Jabbar, A. Bovine ticks harbour a diverse array of microorganisms in Pakistan. Parasit. Vectors 2020, 13, 1. [CrossRef]

108. Gebrekidan, H.; Abbas, T.; Wajid, M.; Ali, A.; Gasser, R.B.; Jabbar, A. Molecular characterisation of Theileria orientalis in imported and native bovines from Pakistan. Infect. Genet. Evol. 2017, 47, 19-25. [CrossRef]

109. Hassan, M.A.; Liu, J.; Sajid, M.S.; Mahmood, A.; Zhao, S.; Abbas, Q.; Guan, G.; Yin, H.; Luo, J. Molecular detection of Theileria annulata in cattle from different regions of Punjab, Pakistan, by using recombinase polymerase amplification and polymerase chain reaction. J. Parasitol. 2018, 104, 196-201. [CrossRef]

110. Rehman, A.; Conraths, F.J.; Sauter-Louis, C.; Krücken, J.; Nijhof, A.M. Epidemiology of tick-borne pathogens in the semi-arid and the arid agro-ecological zones of Punjab province, Pakistan. Transbound. Emerg. Dis. 2019, 66, 526-536.

111. Qayyum, M.; Farooq, U.; Samad, H.A.; Chauhdry, H.R. Prevalence, clinicotherapeutic and prophylactic studies on theileriosis in district Sahiwal (Pakistan). J. Anim. Plant Sci. 2010, 20, 266-270.

112. Parveen, A.; Alkhaibari, A.M.; Asif, M.; Almohammed, H.I.; Naqvi, Z.; Khan, A.; Aktas, M.; Ozubek, S.; Farooq, M.; Iqbal, F. Molecular Epidemiology of Theileria annulata in Cattle from Two Districts in Punjab (Pakistan). Animals 2021, 11, 3443. [CrossRef] [PubMed]

113. Parveen, A.; Ashraf, S.; Khan, A.; Asif, M.; Iqbal, F. Tick and tick-borne diseases in Pakistan. In The Entomological Guide to Rhipicephalus, 1st ed.; Kumar, S., Bayugar, R.C., Sharma, A.K., Miranda, E.M., Chaubey, A.K., Eds.; Nova Science Publishers: New York, NY, USA, 2021.

114. Shahzad, W.; Haider, N.; Mansur-ud-Din, A.; Munir, R.; Saghar, M.S.; Mushtaq, M.H.; Ahmad, N.; Akbar, G.; Mehmood, F. Prevalence and molecular diagnosis of Babesia ovis and Theileria ovis in Lohi sheep at livestock experiment station (LES), Bahadurnagar, Okara, Pakistan. Iran. J. Parasitol. 2013, 8, 570. [PubMed]

115. Riaz, M.; Tasawar, Z. Identification of Theileria species (Theileria ovis and Theileria lestoquardi) by PCR in apparently healthy small ruminants in and around Multan, Southern Punjab, Pakistan. Pakistan. J. Anim. Plant Sci. 2017, 27, 809-818.

116. Habib, F.; Tabbasum, R.; Awais, T.; Sakhawat, A.; Khalil, R.; Sharif, A.; Yousaf, A.; Arshad, M.; Shahnawaz, R.; Shaheen, S.; et al. Prevalence of Bovine Tropical Theileriosis in Cattle in Quetta Balochistan-Pakistan. Arch. Anim. Husb. Dairy Sci. 2021, 2, 1-3. 
117. Chaudhry, U.; Ali, Q.; Rashid, I.; Shabbir, M.Z.; Ijaz, M.; Abbas, M.; Evans, M.; Ashraf, K.; Morrison, I.; Morrison, L.; et al. Development of a deep amplicon sequencing method to determine the species composition of piroplasm haemoprotozoa. Ticks Tick-Borne Dis. 2019, 10, 101276. [CrossRef]

118. Riaz, M.; Nazir, M.M.; Tasawar, Z.; Ahmed, A.N.; Ayaz, M.M.; Akram, Q.; Lindsay, D.S. Molecular epidemiology and prevalence of Theileria lestoquardi and Theileria ovis infection in goats infested with tick vectors from Multan, Pakistan. J. Med. Entomol. 2019, 56, 844-848. [CrossRef]

119. Abid, K.; Bukhari, S.; Asif, M.; Sattar, A.; Arshad, M.; Aktas, M.; Ozubek, S.; Shaikh, R.S.; Iqbal, F. Molecular detection and prevalence of Theileria ovis and Anaplasma marginale in sheep blood samples collected from Layyah district in Punjab, Pakistan. Trop. Anim. Health Prod. 2021, 53, 439. [CrossRef]

120. Farooqi, S.; Ijaz, M.; Saleem, M.; Rashid, M.; Ahmad, S.; Islam, S. Prevalence and molecular diagnosis of Theileria annulata in bovine from three distinct zones of Khyber Pakhtunkhwa province, Pakistan. J. Anim. Plant Sci. 2017, 27, $1836-1841$.

121. Zeb, J.; Shams, S.; Din, I.U.; Ayaz, S.; Khan, A.; Nasreen, N.; Khan, H.; Khan, M.A.; Senbill, H. Molecular epidemiology and associated risk factors of Anaplasma marginale and Theileria annulata in cattle from North-western Pakistan. Vet. Parasitol. 2020, 279, 109044. [CrossRef]

122. Ullah, R.; Shams, S.; Khan, M.A.; Ayaz, S.; ul Akbar, N.; ud Din, Q.; Khan, A.; Leon, R.; Zeb, J. Epidemiology and molecular characterization of Theileria annulata in cattle from central Khyber Pakhtunkhwa, Pakistan. PLoS ONE 2021, 16, e0249417. [CrossRef]

123. Ullah, N.; Durrani, A.Z.; Avais, M.; Nisar, A.; Ullah, S.; Khan, M.S.; Mehmood, K.; Khan, M.A.; Haq, I. Prevalence, risk factors and host biomarkers of ovine theileriosis. Pak. J. Zool. 2018, 50, 1211-1216. [CrossRef]

124. Khan, A.; Niaz, S.; Khan, A.; Ahmed, H.; Khattak, I.; Zeb, J.; Naeem, H.; Hassan, M.A.; Ulucesme, M.C.; Ozubek, S. Molecular detection of small ruminant piroplasmosis and first report of Theileria luwenshuni (Apicomplexa: Theileridae) in small ruminants of Pakistan. Exp. Parasitol. 2020, 212, 107872.

125. Mohsin, M.; Hameed, K.; Kamal, M.; Ali, A.; Rafiq, N.; Usman, T.; Khan, W.; Abbasi, A.A.; Khan, R.U.; Yousafzai, G.J. Prevalence and risk factors assessment of theileriosis in livestock of Malakand Division, Pakistan. J. Saudi Soc. Agric. Sci. 2021. [CrossRef]

126. Niaz, S.; Zia Ur Rahman, I.A.; Cossío-Bayúgar, R.; Amaro-Estrada, I.; Alanazi, A.D.; Khattak, I.; Zeb, J.; Nasreen, N.; Khan, A. Molecular prevalence, characterization and associated risk factors of Anaplasma spp. and Theileria spp. in small ruminants in Northern Pakistan. Parasite 2021, 28, 3. [CrossRef]

127. Bhutto, B.; Gadahi, J.A.; Khuhro, A.; Rajput, H.M.; Bhutto, F.; Rajput, M.A.; Talpur, A.R. A survey on haemo-protozoan parasites in buffaloes of Landhi Dairy Colony, Karachi-Pakistan. Int. J. Agro Vet. Med. Sci. 2012, 6, 73-76. [CrossRef]

128. Ghafar, A.; Koehler, A.V.; Hall, R.S.; Gauci, C.G.; Gasser, R.B.; Jabbar, A. Targeted next-generation sequencing and informatics as an effective tool to establish the composition of bovine piroplasm populations in endemic regions. Microorganisms 2021, 9, 21. [CrossRef]

129. Durrani, S.; Khan, Z.; Khattak, R.M.; Andleeb, M.; Ali, M.; Hameed, H.; Taqddas, A.; Faryal, M.; Kiran, S.; Anwar, H.; et al. A comparison of the presence of Theileria ovis by PCR amplification of their SSU rRNA gene in small ruminants from two provinces of Pakistan. Asian Pac. J. Trop. Dis. 2012, 2, 43-47. [CrossRef]

130. Karim, S.; Budachetri, K.; Mukherjee, N.; Williams, J.; Kausar, A.; Hassan, M.J.; Adamson, S.; Dowd, S.E.; Apanskevich, D.; Arijo, A. A study of ticks and tick-borne livestock pathogens in Pakistan. PLoS Negl. Trop. Dis. 2017, 11, e0005681. [CrossRef]

131. Ashfaque, M.; Ajmal, M.; Ahmad, S. An outbreak of theileriosis in crossbred neonate calves. Pak. Vet. J. 1983, 3, 44-46.

132. Muhammad, G. Clinico-epidemiological and therapeutic aspects of bovine theileriosis. Bull Calf Appear Female 1999, 36, 32.

133. Khan, M.Q.; Zahoor, A.; Jahangir, M.; Mirza, M.A. Prevalence of blood parasites in cattle and buffaloes. Pak. Vet. J. 2004, 24, 193-194.

134. Zahid, I.A.; Latif, M.; Baloch, K.B. Incidence and treatment of theileriasis and babesiasis. Pak. Vet. J. 2005, $25,137$.

135. Durrani, A.; Kamal, N.; Khan, M.S. Incidence of theileriosis and estimation of packed cell volume, total erythrocyte count and hemoglobin in buffaloes. J. Anim. Plant Sci. 2006, 16, 85-88.

136. Durrani, A.Z.; Kamal, N. Identification of ticks and detection of blood protozoa in friesian cattle by polmerase chain reacton test and estimation of blood parameters in district Kasur, Pakistan. Trop. Anim. Health Prod. 2008, 40, 441-447. [CrossRef] [PubMed]

137. Azizi, H.; Shiran, B.; Dehkordi, A.F.; Salehi, F.; Taghadosi, C. Detection of Theileria annulata by PCR and its comparison with smear method in native carrier cows. Biotechnology 2008, 7, 574-577. [CrossRef]

138. Atif, F.A.; Khan, M.S.; Iqbal, H.J.; Arshad, G.M.; Ashraf, E.; Ullah, S. Prevalence of Anaplasma marginale, Babesia bigemina and Theileria annulata infections among cattle in Sargodha District, Pakistan. Afr. J. Agric. Res. 2012, 7, 302-3307.

139. Hassan, M.A.; Liu, J.; Sajid, M.S.; Rashid, M.; Mahmood, A.; Abbas, Q.; Guan, G.; Yin, H.; Luo, J. Simultaneous detection of Theileria annulata and Theileria orientalis infections using recombinase polymerase amplification. Ticks Tick-Borne Dis. 2018, 9, 1002-1005. [CrossRef]

140. Irshad, N.; Qayyum, M.; Hussain, M.; Khan, M.Q. Prevalence of tick infestation and theileriosis in sheep and goats. Pak. Vet. J. 2010, 30, 178-180.

141. Shabbir, M.Z.; Khan, J.A. Prevalence of theileriosis in sheep in Okara District, Pakistan. Pak. J. Zool. 2010, 42, 639-643.

142. Durrani, A.Z.; Younus, M.; Kamal, N.; Mehmood, N.; Shakoori, A.R. Prevalence of ovine Theileria species in district Lahore, Pakistan. Pak. J. Zool. 2011, 43, 57-60. 
143. Naz, S.; Maqbool, A.; Ahmed, S.; Ashraf, K.; Ahmed, N.; Saeed, K.; Latif, M.; Iqbal, J.; Ali, Z.; Shafi, K. Prevalence of theileriosis in small ruminants in Lahore-Pakistan. J. Vet. Anim. Sci. 2012, 2, 16-20.

144. Fatima, M.; Saeed, S.; Shaikh, R.S.; Ali, M.; Iqbal, F. A study on molecular detection of Theileria lestoquardi by PCR amplification in apparently healthy small ruminants from five districts of Southern Punjab. Pak. J. Zool. 2015, 47, 441-446.

145. Riaz, M.; Tasawar, Z. A study on molecular surveillance of Theileria spp. infection and its impact on hematological and biochemical changes in naturally infected small ruminants at Multan, Pakistan. Pure Appl. Biol. 2017, 6, 1427-1435. [CrossRef]

146. Afridi, Z.K.; Ahmad, I. Incidence of anaplasmosis, babesiosis and theileriosis in dairy cattlein Peshawar [Pakistan]. Sarhad J. Agric. 2005, 21, 311-316.

147. Iqbal, F.; Khattak, R.M.; Ozubek, S.; Khattak, M.N.K.; Rasul, A.; Aktas, M. Application of the reverse line blot assay for the molecular detection of Theileria and Babesia sp. in sheep and goat blood samples from Pakistan. Iran. J. Parasitol. $2013,8,289$.

148. Zeb, J.; Shams, S.; Ayaz, S.; Din, I.U.; Khan, A.; Adil, N.; Ullah, H.; Raza, A. Epidemiology of ticks and molecular characterization of Rhipicephalus microplus in cattle population in North-Western Pakistan. Int. J. Acarol. 2020, 46, 335-343. [CrossRef]

149. Khan, A.; Jamil, M.; Ali, A.; Ali, A.; Imdad, S.; Zeeshan, M. Prevalence of Theileriosis in Buffaloes at Government and Private Farms in Tehsil Paharpur, Dera Ismail Khan. Int. J. Mod. Agric. 2021, 10, 4360-4363.

150. Saeed, S.; Jahangir, M.; Fatima, M.; Shaikh, R.S.; Khattak, R.M.; Ali, M.; Iqbal, F. PCR based detection of Theileria lestoquardi in apparently healthy sheep and goats from two districts in Khyber Pukhtoon Khwa (Pakistan). Trop. Biomed. $2015,32,225-232$.

151. Anwar, K.; Din, A. Epidemiology of Tick Borne Heamoprotozoan Infection in Ruminants in District Peshawar, and Periphery, Khyber Pakhtunkhwa,(Pakistan). Am. Sci. Res. J. Eng. Technol. Sci. 2017, 35, 191-200.

152. Shah, S.S.A.; Khan, M.I.; Rahman, H.U. Epidemiological and hematological investigations of tick-borne diseases in small ruminants in Peshawar and Khyber agency. Pak. J. Adv. Parasitol. 2017, 4, 15-22.

153. Ullah, N.; Durrani, A.Z.; Ullah, S.; Ullah, S.; Shah, M.K.; Khan, A.Z.; Khan, M.S.; Khan, N.U.; Khan, M.A. A study on potential factors and physiological biomarkers associated with the occurrence of ovine theileriosis. Small Rumin. Res. 2018, 168, 32-38. [CrossRef]

154. Buriro, S.N.; Phulan, M.S.; Arijo, A.H.; Memon, A.B. Incidence of some haemo-protozoans in Bos indicus and Bubalis bubalis in Hyderabad. Pak. Vet. J. 1994, 14, 28-29.

155. Abbasi, F.; Abbasi, I.H.R.; Nissa, T.F.; Bhutto, Z.A.; Arain, M.A.; Soomro, R.N.; Siyal, F.A.; Fazlani, S.A. Epidemiological study of tick infestation in buffalo of various regions of district Khairpur, Pakistan. Vet. World 2017, 10, 688-694. [CrossRef] [PubMed]

156. Soomro, M.H.; Soomro, S.P.; Bhutto, M.B.; Akbar, Z.; Yaqoob, M.; Arijo, A.G. Prevalence of ticks in buffaloes in the upper Sindh Pakistan. Buffalo Bull. 2014, 33, 323-327.

157. Durrani, A.Z.; Shakoori, A.R. Study on ecological growth conditions of cattle Hyalomma ticks in Punjab, Pakistan. Iran. J. Parasitol. 2009, 14, 19-25.

158. Rehman, A.; Nijhof, A.M.; Sauter-Louis, C.; Schauer, B.; Staubach, C.; Conraths, F.J. Distribution of ticks infesting ruminants and risk factors associated with high tick prevalence in livestock farms in the semi-arid and arid agro-ecological zones of Pakistan. Parasit. Vectors 2017, 10, 190. [CrossRef]

159. Zahida, T.; Sumaira, N.; Lashari, M.H. The prevalence of ixodid ticks on buffaloes at private animal farm Bibipur, Multan. Glob. Vet. 2014, 12, 154-157.

160. Khan, M.N.; Hayar, C.S.; Iqbal, Z.; Hayat, B. Prevalence of ticks on livestock in Faisalabad (Pakistan). Pak. Vet. J. $1993,13,182$.

161. Ramzan, M.; Khan, M.S.; Avais, M.; Khan, J.A.; Pervez, K.; Shahzad, W. Prevalence of ecto parasites and comparative efficacy of different drugs against tick infestation in cattle. J. Anim. Plant Sci. 2008, 18, 17-19.

162. Ahmed, S.; Numan, M.; Manzoor, A.W.; Ali, F.A. Investigations into Ixodidae ticks in cattle in Lahore, Pakistan. Vet. Ital. 2012, 48, 185-191.

163. Nasreen, N.; Niaz, S.; Khan, A.; Ayaz, S.; Rashid, M.; Khattak, I.; Yu, Z.; Wang, T.; Al Sarraf, M.; Ali, A. Molecular characterization of ticks infesting livestock in Khyber Pakhtunkhwa Province, Pakistan. Int. J. Acarol. 2020, 46, 165-170. [CrossRef]

164. Hussain, S.I.; Kumar, G.A. Prevalence of ticks (Ixodoidea, Ixodidae) of buffaloes at Thatta and its adjoining areas in the Province of Sindh, Pakistan. Pak. Congr. Zool. 1990, 10, 11-16.

165. Rafique, N.; Kakar, A.; Iqbal, A.; Masood, Z.; Razzaq, W.; Iqbal, F. Impact assessment of tick species, Rhipicephalus (Boophilus) microplus on the milk productions of cattle's in the Quetta City of Province Balochistan, Pakistan. Glob. Vet. 2015, 15, 19-23.

166. Sajid, M.S.; Iqbal, Z.; Khan, M.N.; Muhammad, G. Point prevalence of hard ticks (Ixodids) infesting domestic ruminants of lower Punjab, Pakistan. Int. J. Agric. Biol. 2008, 10, 349-351.

167. Rafiq, N.; Kakar, A.; Ghani, A.; Iqbal, A.; Achakzai, W.M.; Sadozai, S.; Shafiq, M.; Mengal, M.A. Ixodid ticks (Arachnida: Acari) prevalence associated with risk factors in the bovine host in District Quetta, Balochistan. Pak. J. Zool. 2017, 46, $2113-2121$. [CrossRef]

168. Bibi, S.; Rafique, N.; Kareem, A.; Taj, M.K.; Iqbl, K.; Bibi, A.; Shafiq, M.; Ghafoor, G.; Ghafoor, A.; Ijaz, A. 15. Prevalence and taxonomic identification of hard ticks (Ixodidea) found in livestock of Harnai District, Balochistan, Pakistan. Pure Appl. Biol. 2020, 9, 2330-2338. [CrossRef]

169. Cruz, D.D.; Arellano, E.; Denis Ávila, D.; Ibarra-Cerdeña, C.N. Identifying Chagas disease vectors using elliptic Fourier descriptors of body contour: A case for the cryptic dimidiata complex. Parasit. Vectors 2020, 13, 332. [CrossRef]

170. Batool, M.; Nasir, S.; Rafique, A.; Yousaf, I.; Yousaf, M. Prevalence of tick infestation in farm animals from Punjab, Pakistan. Pak. Vet. J. 2019, 39, 406-410. [CrossRef] 
171. Sajid, M.S.; Iqbal, Z.; Khan, M.N.; Muhammad, G.; Needham, G.; Khan, M.K. Prevalence, associated determinants, and in vivo chemotherapeutic control of hard ticks (Acari: Ixodidae) infesting domestic goats (Capra hircus) of lower Punjab, Pakistan. Parasitol. Res. 2011, 108, 601-609. [CrossRef]

172. Iqbal, A.; Siddique, F.; Mahmood, M.S.; Shamim, A.; Zafar, T.; Rasheed, I.; Saleem, I.; Ahmad, W. Prevalence and impacts of ectoparasitic fauna infesting goats (Capra hircus) of district Toba Tek Singh, Punjab Pakistan. Glob. Vet. 2014, 12, 158-164.

173. Ramzan, M.; Naeem-Ullah, U.; Abbas, H.; Adnan, M.; Rasheed, Z.; Khan, S. Diversity of hard ticks in goats and sheep in Multan, Punjab, Pakistan. Int. J. Agric. Biol. Res. 2019, 35, 7-9.

174. Ramzan, M.; Naeem-Ullah, U.; Saba, S.; Iqbal, N.; Saeed, S. Prevalence and identification of tick species (Ixodidae) on domestic animals in district Multan, Punjab Pakistan. Int. J. Acarol. 2020, 46, 83-87. [CrossRef]

175. Siddiqi, M.N.; Jan, A.H. Ixodid ticks (ixodidae) of NWFP (Pakistan). Pak. Vet. J. 1986, 6, 124-126.

176. Shah, A.; Shah, S.R.; Rafi, M.A.; Noorrahim, M.S.; Mitra, A. Identification of the prevalent ticks (Ixodid) in goats and sheep in Peshawar, Pakistan. J. Entomol. Zool. Stud. 2015, 3, 11-14.

177. Ali, A.; Khan, M.A.; Zahid, H.; Yaseen, P.M.; Qayash Khan, M.; Nawab, J.; Ur Rehman, Z.; Ateeq, M.; Khan, S.; Ibrahim, M. Seasonal Dynamics, Record of Ticks Infesting Humans, Wild and Domestic Animals and Molecular Phylogeny of Rhipicephalus microplus in Khyber Pakhtunkhwa Pakistan. Front. Physiol. 2019, 10, 793. [CrossRef] [PubMed]

178. Aziz, S.; Shah, S.F.; Amin, F.; Khan, M.A.; Ahmad, M. Taxonomic Study of Arthropod Pests of Livestock in District Peshawar, Khyber Pakhtunkhwa. Pak. J. Life Soc. Sci. 2018, 16, 85-96.

179. Khatoon, N.; Noureen, S.; Khan, Z.; Gul, S.U.; Ur, H. Domestic animals ectoparasite fauna of district Karak, KP, Pakistan. Int. J. Biosci. 2018, 13, 384-388.

180. Khan, A.; Nasreen, N.; Niaz, S.; Sajjad Ali Shah, S.; Mitchell III, R.D.; Ayaz, S.; Naeem, H.; Khan, L.; De León, A.P. Tick burden and tick species prevalence in small ruminants of different agencies of the Federally Administered Tribal Areas (FATA), Pakistan Int. J. Acarol. 2019, 45, 374-380. [CrossRef]

181. Hussain, S.I.; Kumar, G.A. Prevalence of ixodid ticks (Ixodoidea, Ixodidae) of goats at Khairpur Mir's and its adjoining areas [Pakistan]. Pak. J. Zool. 1983, 15, 51-55.

182. Hussain, S.I.; Kumar, G.A. The incidence of ticks (Ixodoidea: Ixodidae) infesting sheep and goats in Sind province, Pakistan. Pak. J. Zool. 1985, 17, 89-97.

183. Iqbal, A.; Nawaz, M. Taxonomic studies of Haemaphysalis flava (Neumann), its seasonal prevalence and role in parasitic diseases of sheep/goat in Balochistan. Pak. Entomol. 2007, 29, 1-4.

184. Haneef, M.; Kakar, A.; Naseem, M.; Kurd, A.; Rafiq, N.; Kakar, B.; Uddin, S. 40. Incidence of ectoparasite in chiltan wild goat (Artiodactyla: Caprinae) native of Hazarganji chiltan national park (HCNP), Balochistan, Pakistan. Pure Appl. Biol. 2019, 8 , 389-396.

185. Kasi, K.K.; von Arnim, F.; Schulz, A.; Rehman, A.; Chudhary, A.; Oneeb, M.; Sas, M.A.; Jamil, T.; Maksimov, P.; Sauter-Louis, C. Crimean-Congo haemorrhagic fever virus in ticks collected from livestock in Balochistan, Pakistan. Transbound. Emerg. Dis. 2020, 67, 1543-1552. [CrossRef] [PubMed]

186. Ahmed AKNU Blood parasites of domestic animals in Bangladesh. Bangladesh Vet. J. 1976, 10, 69-71.

187. Al Mahmud, M.A.; Belal, S.M.S.H.; Hossain, M.A. Prevalence of theileriosis and babesiosis in cattle in Sirajganj district of Bangladesh. Res. Agric. Livest. Fish. 2015, 2, 79-86. [CrossRef]

188. Roy, B.C.; Estrada-Peña, A.; Krücken, J.; Rehman, A.; Nijhof, A.M. Morphological and phylogenetic analyses of Rhipicephalus microplus ticks from Bangladesh, Pakistan and Myanmar. Ticks Tick-Borne Dis. 2018, 9, 1069-1079. [CrossRef]

189. Islam, M.F.; Rudra, P.G.; Singha, S.; Das, T.; Gebrekidan, H.; Uddin, M.B.; Chowdhury, M.Y.E. Molecular Epidemiology and Characterization of Theileria in Goats. Protist 2021, 172, 125804. [CrossRef]

190. Siddiki, A.Z.; Uddin, M.B.; Hasan, M.B.; Hossain, M.F.; Rahman, M.M.; Das, B.C.; Sarker, M.S.; Hossain, M.A. Coproscopic and Haematological Approaches to Determine the Prevalence of Helminthiasis and Protozoan Diseases of Red Chittagong Cattle (RCC) Breed in Bangladesh. Pak. Vet. J. 2010, 30, 1-6.

191. Kispotta, S.; Islam, M.F.; Hoque, M.F.; Rahman, M.S.; Borman, A.; Haque, M.A.; Rahman, M.R. Study of prevalence and associated risk factors of anaplasmosis and theileriasis in cattle. Asian J. Med. Biol. Res. 2016, 2, 567-576. [CrossRef]

192. Ali, M.W.; Alauddin, M.; Azad, M.T.A.; Hasan, M.A.; Appiah-Kwarteng, C.; Takasu, M.; Baba, M.; Kitoh, K.; Rahman, M.; Takashima, Y. Theileria annulata seroprevalence among different cattle breeds in Rajshahi Division, Bangladesh. J. Vet. Med. Sci. 2016, 78, 1577-1582. [CrossRef]

193. Moni, M.I.Z.; Hayashi, K.; Sivakumar, T.; Rahman, M.; Nahar, L.; Islam, M.Z.; Yokoyama, N.; Kitoh, K.; Appiah-Kwarteng, C.; Takashima, Y. First Molecular detection of Theileria annulata in Bangladesh. J. Vet. Med. Sci. 2019, 81, 1197-1200. [CrossRef] [PubMed]

194. Hassan, M.Z.; Giasuddin, M.; Rahman, M.M.; Ershaduzzaman, M.; Hasan, M. Identification of vector-borne blood protozoa in cattle and sheep in Bangladesh. J. Virol. Antivir. 2019, $2,4$.

195. Samad, A.; Dhar, S.; Gautam, O.P. Prevalence of Theileria annulata infection among cattle of Bangladesh. Indian J. Parasitol. 1983, 7, 61-63.

196. Samad, M.A.; Bashar, S.A.; Shahidullah, M.; Ahmed, M.U. Prevalence of haemoprotozoan parasites in cattle of Bangladesh. Indian Vet. Med. J. 1989, 13, 50-51. 
197. Dhar, S.; Gautam, O.P. Theileria annulata infection of cattle I complement fixation and coagulating absorption tests for serodiagnosis. Indian J. Anim. Sci. 1977, 47, 389-394.

198. Ros-García, A.; Nicolás, A.; García-Pérez, A.L.; Juste, R.A.; Hurtado, A. Development and evaluation of a real-time PCR assay for the quantitative detection of Theileria annulata in cattle. Parasit. Vectors 2012, 5, 171. [CrossRef]

199. Chae, J.; Allsopp, B.A.; Waghela, S.D.; Park, J.; Kakuda, T.; Sugimoto, C.; Allsopp, M.T.E.P.; Wagner, G.G.; Holman, P.J. A study of the systematics of Theileria spp. based upon small-subunit ribosomal RNA gene sequences. Parasitol. Res. 1999, 85, 877-883. [CrossRef]

200. Glidden, C.K.; Koehler, A.V.; Hall, R.S.; Saeed, M.A.; Coppo, M.; Beechler, B.R.; Charleston, B.; Gasser, R.B.; Jolles, A.E.; Jabbar, A. Elucidating cryptic dynamics of Theileria communities in African buffalo using a high-throughput sequencing informatics approach. Ecol. Evol. 2020, 10, 70-80. [CrossRef]

201. Ogden, N.H.; Ben Beard, C.; Ginsberg, H.S.; Tsao, J.I. Possible Effects of Climate Change on Ixodid Ticks and the Pathogens They Transmit: Predictions and Observations. J. Med. Entomol. 2021, 58, 1536-1545. [CrossRef] 